\title{
A Field-Based Experiment on the Influence of Stand Density Reduction on Watershed Processes at the Caspar Creek Experimental Watersheds in Northern California
}

\section{OPEN ACCESS}

Edited by:

Tom Grant Pypker,

Thompson Rivers University, Canada

Reviewed by:

Elliott Kelliner,

West Virginia University, United States

Fengjing Liu,

Michigan Technological University,

United States

Christina (Naomi) Tague,

University of California,

Santa Barbara, United States

*Correspondence:

Salli F. Dymond

sdymond@d.umn.edu

Specialty section: This article was submitted to

Forest Hydrology,

a section of the journal

Frontiers in Forests and Global

Change

Received: 07 April 2021 Accepted: 24 June 2021 Published: 15 July 2021

Citation:

Dymond SF, Richardson PW, Webb LA, Keppeler ET, Arismendi I, Bladon KD, Cafferata PH, Dahlke HE, Longstreth DL, Brand PK, Ode PR, Surfleet $C G$ and Wagenbrenner JW (2021) A Field-Based Experiment on

the Influence of Stand Density Reduction on Watershed Processes at the Caspar Creek Experimental Watersheds in Northern California.

Front. For. Glob. Change 4:691732.

doi: 10.3389/ffgc.2021.691732

\begin{abstract}
Salli F. Dymond ${ }^{1 *}$, Paul W. Richardson ${ }^{2}$, Lynn A. Webb ${ }^{3}$, Elizabeth T. Keppeler 4 , Ivan Arismendi ${ }^{5}$, Kevin D. Bladon ${ }^{6}$, Peter H. Cafferata ${ }^{7}$, Helen E. Dahlke ${ }^{8}$, David L. Longstreth ${ }^{9}$, Patrick K. Brand ${ }^{9}$, Peter R. Ode ${ }^{10}$, Christopher G. Surfleet ${ }^{11}$ and Joseph W. Wagenbrenner ${ }^{2}$

${ }^{1}$ Department of Earth and Environmental Sciences, University of Minnesota Duluth, Duluth, MN, United States, ${ }^{2}$ Pacific Southwest Research Station, USDA Forest Service, Arcata, CA, United States, ${ }^{3}$ California Department of Forestry and Fire Protection, Fort Bragg, CA, United States, ${ }^{4}$ Pacific Southwest Research Station, USDA Forest Service, Fort Bragg, CA, United States, ${ }^{5}$ Department of Fisheries, Wildlife, and Conservation Sciences, Oregon State University, Corvallis, OR, United States, ${ }^{6}$ Department of Forest Engineering, Resources \& Management, Oregon State University, Corvallis, OR, United States, ${ }^{7}$ California Department of Forestry and Fire Protection, Sacramento, CA, United States, ${ }^{8}$ Department of Land, Air and Water Resources, University of California, Davis, Davis, CA, United States, ${ }^{9}$ California Geological Survey, Santa Rosa, CA, United States, ${ }^{10}$ California Department of Fish and Wildlife, Office of Spill Prevention and Response, Aquatic Bioassessment Laboratory, Rancho Cordova, CA, United States, ${ }^{11}$ Department of Natural Resources Management \& Environmental Sciences, California Polytechnic State University, San Luis Obispo, CA, United States
\end{abstract}

Forests are integral to sustaining clean water resources and healthy watersheds. It is critical, therefore, that managers fully understand the potential impacts of their actions on myriad ecosystem services provided by forested watersheds. While forest hydrologists have long used paired-watershed experiments to elucidate the complex interactions between forest management and watershed biogeochemical and ecohydrological processes, there is still much to learn from these studies. Here, we present an overview of the process for designing a paired-watershed study using a large harvesting experiment at the Caspar Creek Experimental Watersheds in coastal California as an example. We detail many considerations when designing such an experiment and highlight the wide range of scientific investigations that are part of the larger experiment. Paired watershed studies are a great example of community engaged scholarship and offer the unique opportunity to work with land managers to solve applied problems while simultaneously discovering new fundamental knowledge about how watersheds function.

Keywords: forest hydrology, timber harvest, ecohydrology, forest management, catchment

\section{INTRODUCTION}

Healthy forested headwater watersheds are critical for provision of a wide range of ecosystem services, including terrestrial and aquatic habitat, flood mitigation through storage of water, and the majority of drinking water supplies throughout the world (Sedell et al., 2000). Thus, effective and sustainable management of these headwater ecosystems is vital for ensuring the maintenance 
of a broad range of economic and ecological goods and services. The connection between forests and clean water resources has long been documented, with the first experimental investigations dating back to the early 20th century (e.g., Bates, 1921). Worldwide, the predominant method for testing the impacts of forest management on water resources has been the paired watershed study (e.g., Neary, 2016). The first paired watersheds in the United States were implemented by the USDA Forest Service in the early 1900s, with at least 40 sites established worldwide by the late 1960s (Neary, 2016). The ultimate goal of these studies was to understand how forest practices affected streamflow and sediment production (Lugo et al., 2006; Neary, 2016). These paired watershed studies, located in a wide range of ecosystems and climates, found similar water yield results regardless of topography or vegetation type-removing $>20 \%$ of basal area from a stand typically resulted in measurable increases in streamflow (Hibbert, 1967; Stednick, 1996). Increases in water yield were attributed to decreased evapotranspiration and interception loss that occur when removing vegetation from a watershed (Brown et al., 2005). As forests regenerate, the effects on streamflow generally diminish with recent evidence illustrating longer-term declines in summer low flows due to greater evapotranspiration rates (Reid, 2012; Perry and Jones, 2017; Coble et al., 2020; Segura et al., 2020).

While scientists generally understand the impacts of forest harvesting on water yield, there are still fundamental questions regarding the role that forests play in controlling the storage and release of water (e.g., Grant et al., 2003; McDonnell et al., 2018). Understanding the linkages between forests and water is especially relevant for forests that have undergone disturbance such as harvesting, wildfire, or insect outbreaks, as the response of water resources in a watershed might be very different depending on the type or degree of disturbance severity (e.g., Ebel and Mirus, 2014; Biederman et al., 2015; Kinoshita and Hogue, 2015; Bladon et al., 2019; Niemeyer et al., 2020). Similarly, while there is general consensus that sediment generation has decreased in experimental watersheds with improved forest practices (e.g., Harr, 1982; Richardson et al., 2018), the degree that remaining effects from timber operations should be reduced continues to be debated (Loehle et al., 2014). While paired watershed studies have answered key questions on cause and effect, the question of equifinality - the idea that a given end state can be achieved by multiple potential means-still remains.

The USDA Forest Service and the California Department of Forestry and Fire Protection (CAL FIRE) established the Caspar Creek Experimental Watersheds as a paired watershed study in 1961. Until 2017, there had been two experimental paired watershed studies at the research site. A selection harvest with tractor yarding in the early 1970s removed approximately twothirds of the existing timber volume in the South Fork during the First Experiment (Rice et al., 1979). Clearcut logging and cable yarding from 1985 to 1992 removed about 50\% of the timber in the North Fork in the Second Experiment (Ziemer, 1998). Results from the first two studies at Caspar Creek have contributed to the body of knowledge for a wide range of watershed topics, including cumulative effects, changes in peak flows with timber harvest, logging-related sediment production, buffer strip design, logging-related impacts on anadromous fish and benthic macro-invertebrate communities, management of headwater channels, impacts of timber harvesting on subsurface flow, nutrient cycling effects associated with clearcutting, changes in fog drip and interception loss with harvest, and design of water quality monitoring programs (Lisle, 1989; Keppeler and Ziemer, 1990; Wright et al., 1990; Cafferata and Reid, 2013; Carr et al., 2013; Keppeler and Lewis, 2007). In 2000, planning began for the Third Experiment. The Third Experiment was designed to broaden process-based understanding of forest hydrology by investigating how contemporary forest management, including timber harvest and road construction, affects water movement and storage, streamflow, and sediment production and delivery.

In the following sections, we describe the experimental site (see section "The Caspar Creek Experimental Watersheds"), present an overview of the experimental design and offer general suggestions for designing paired watershed experiments (see section "Designing the Third Experiment"), discuss the choice of control sub-watersheds and make suggestions on how to pair watersheds at other experimental locations (see section "Associated Studies of the Third Experiment"), summarize individual projects associated with the Caspar Creek Third Experiment (see section "Harvesting Implementation and Results"), and present results of the partial selection timber harvest (see section "Concluding Remarks"). We expect information regarding our experimental design to benefit others interested in designing new paired watershed experiments. Our goal is to introduce the Third Experiment to the broader research community, highlight the multitude of research opportunities nested within paired watershed studies, and provide a possible template for designing new paired watershed experiments.

\section{THE CASPAR CREEK EXPERIMENTAL WATERSHEDS}

The Caspar Creek Experimental Watersheds $\left(39^{\circ} 21^{\prime} \mathrm{N}\right.$, $123^{\circ} 44^{\prime} \mathrm{W}$ ) consist of two study watersheds (the North Fork and South Fork). They are located approximately $7 \mathrm{~km}$ from the Pacific Ocean on the Jackson Demonstration State Forest (JDSF) in northwestern California (Figure 1; Henry, 1998). The Caspar Creek watershed drains an overall area of 2,160 ha to the Pacific Ocean, with the North and South Forks encompassing 479 and 417 ha, respectively.

The climate at Caspar Creek is Mediterranean, with cool, dry summers characterized by coastal fog and mild, moist winters. The 30-year mean annual precipitation, measured near the confluence of the South Fork and North Fork from 1989 to 2018, was $1168 \mathrm{~mm}$. Snowfall is rare in the Caspar Creek watershed and over $90 \%$ of the rainfall occurs between October to April. The monthly air temperature measured near the South Fork weir from 1989 to 2018 averaged $6.1^{\circ} \mathrm{C}$ in December and $13.7^{\circ} \mathrm{C}$ in August. The landscape is dominated by coast redwood [Sequoia sempervirens (D. Don) Endl.], Douglas-fir [Pseudotsuga menziesii (Mirb.) Franco], grand fir [Abies grandis (Doug. ex D. Don) Lindl.], and western hemlock [Tsuga heterophylla (Raf.) Sarg.], with smaller amounts of tanoak [Notholithocarpus 


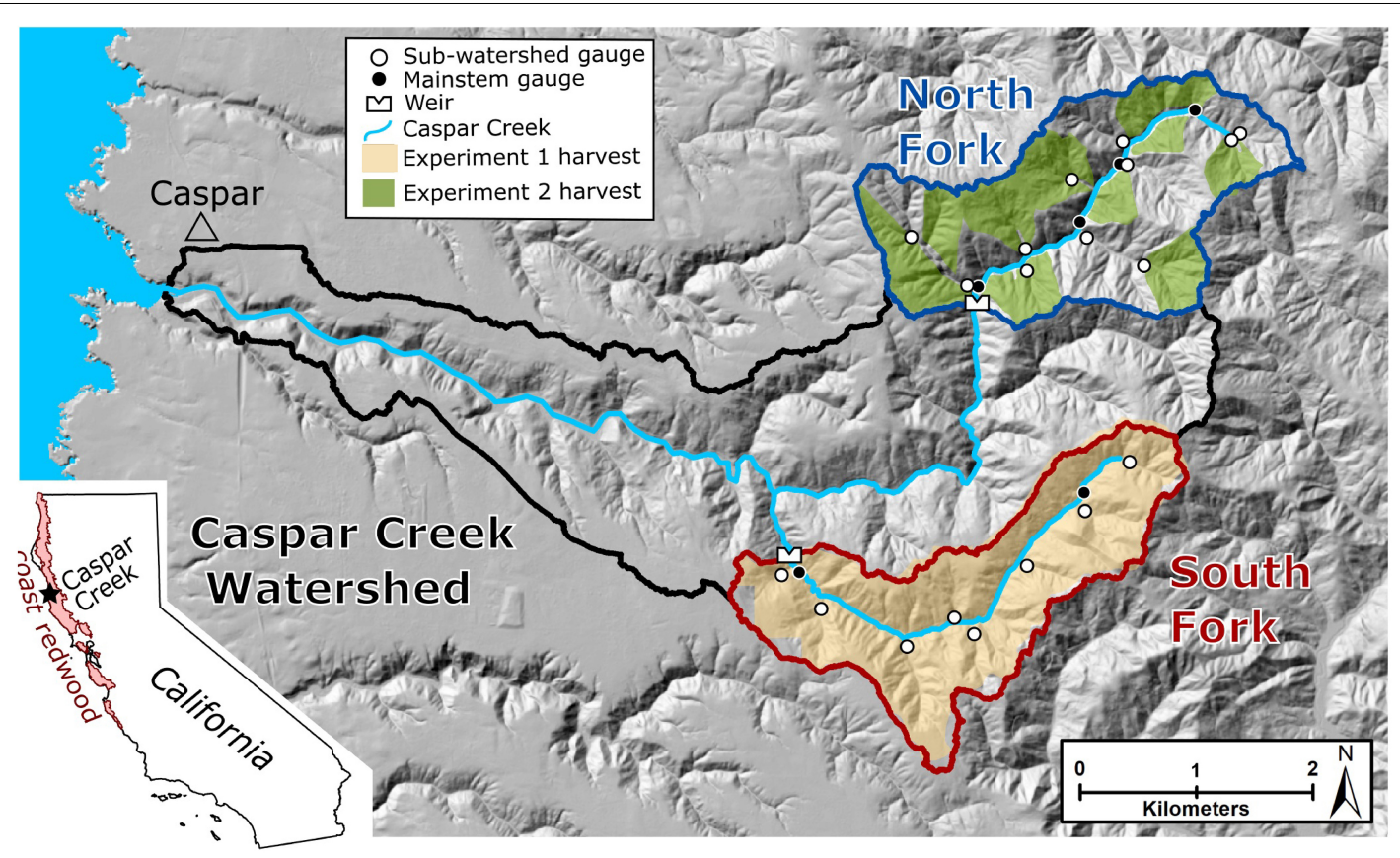

FIGURE 1 | Shaded relief map showing the Caspar Creek Experimental Watersheds and the surrounding region. The inset map shows the location of Caspar Creek and the modern extent of coast redwood. The harvest for the First Experiment was from 1971 to 1973 and the harvest for the Second Experiment was from 1989 to 1992. The weirs were installed in 1962 and have been continuously operational. Installation of the North Fork sub-watershed gages began in 1984 . South Fork sub-watershed gages were installed in 2000. The Caspar Creek outlet is located at $39.362^{\circ} \mathrm{N}, 123.816^{\circ} \mathrm{W}$. The modern extent of coast redwood boundary was supplied by Save the Redwoods League. The shaded relief map was created from LiDAR data collected in 2017 gridded to $10-\mathrm{m}$ horizontal resolution.

densiflorus (Hook. \& Arn.) Manos, Cannon \& Oh], red alder (Alnus rubus Bong.), and bishop pine (Pinus muricata D. Don). Old growth coast redwood timber harvesting took place from 1860 to 1904 (Henry, 1998). Elevation in the experimental watersheds ranges from 37 to $320 \mathrm{~m}$ and hillslope gradients can be steeper than $50 \%$. Soils in the basin are predominantly well-drained clay-loam Ultisols and Alfisols derived from the Coastal Belt of the Franciscan Complex (Rittiman and Thorson, 2006), which primarily includes graywacke and shale (Langenheim et al., 2013).

Since their establishment in 1961, the Caspar Creek Experimental Watersheds have provided foresters, land managers, researchers, and citizens with information that has influenced forest management in northwestern California. The primary goal in establishing Caspar Creek was to improve understanding of how timber harvesting affects streamflow and suspended sediment concentrations (SSC). The First Experiment (1962-1985) was a classic paired watershed study undertaken before the implementation of the modern California Forest Practice Rules (CFPRs). In that study, roads were constructed near stream channels in the South Fork and $60-70 \%$ of the stand volume was selectively cut and tractor yarded while the North Fork served as a control (Rice et al., 1979). The Second Experiment (1985-2017) was designed to address cumulative watershed effects using the new CFPRs by investigating how clearcutting sub-watersheds using cable yarding techniques in the North Fork influenced downstream streamflow and SSC (Ziemer, 1998; Lewis et al., 2001).
Streamflow and SSC measurements began in 2000 at a network of sub-watersheds in the South Fork in anticipation of a Third Experiment to investigate the impact of harvesting under updated CFPRs. The ultimate goal of the Third Experiment is to better understand how current forest management practices including timber harvest and forest road management affect watersheds in the coast redwood region. To meet this objective, stand density in each of the gaged sub-watersheds was either maintained to serve as experimental controls or incrementally reduced. Research studies associated with the Third Experiment range from biological, geological, and hyrological and cover vast spatial and temporal scales (see Section "Associated Studies of the Third Experiment" and Figure 2, below). At the time of the experimental harvest the forest in the South Fork was a mix of approximately 110-150-year-old second growth and approximately 45-year-old third growth.

\section{DESIGNING THE THIRD EXPERIMENT}

\section{How Paired Watersheds Work}

The paired watershed approach is relatively simple in its design. A minimum of two watersheds that have similar characteristics (i.e., size, aspect, elevation, slopes, soils, geology, climate, vegetation) are instrumented and the response variable of interest is measured. For hydrologists, this response variable has typically included annual water yield or peak flow, but measurements can also include water quality parameters, groundwater, or other 


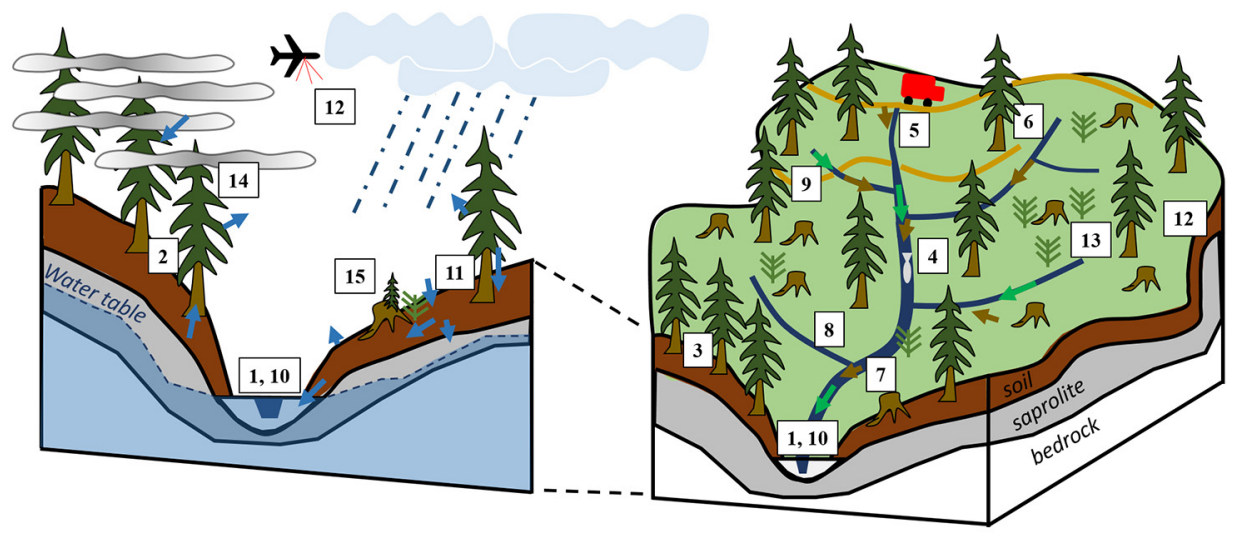

\begin{tabular}{cllllcc}
\hline $\begin{array}{c}\text { Study } \\
\text { No. }\end{array}$ & \multicolumn{1}{c}{ Study Name } & $\begin{array}{c}\text { Measurement } \\
\text { Type }\end{array}$ & $\begin{array}{c}\text { Primary } \\
\text { Study } \\
\text { System }\end{array}$ & Spatial Scale & $\begin{array}{c}\text { Study } \\
\text { Start } \\
\text { Year }\end{array}$ & $\begin{array}{c}\text { Time } \\
\text { Scale* } \\
\text { (years) }\end{array}$ \\
\hline 1 & Watershed Resilience \& Recovery & Continuous & Hydrological & Watershed & 2001 & $20+$ \\
2 & Plant-Soil-Water Dynamics & Continuous & Hydrological & Sub-Watershed & 2015 & 5 \\
3 & Water Worlds & Point, Repeated & Hydrological & Sub-Watershed & 2015 & 5 \\
4 & Bioassessment & Point, Repeated & Biological & Watershed & 2016 & 5 \\
5 & Sediment Effects of Forest Roads & Modeling & Geological & Sub-Watershed & 2017 & 1 \\
6 & Stream Buffers \& Temperatures & Modeling & Hydrological & Watershed & 2017 & NA \\
7 & Sediment Fingerprinting & Point, Repeated & Geological & Watershed & 2016 & 4 \\
8 & Fine Sediment & Reanalysis & Geological & Sub-Watershed & 2016 & NA \\
9 & Road Rehabilitation & Point, Repeated & Geological & Sub-Watershed & 2010 & $15+$ \\
10 & Nutrient & Point, Repeated & Hydrological & Sub-Watershed & 2016 & 4 \\
11 & Interception \& Throughfall & Continuous & Hydrological & Plot & $2006^{\text {a }}$ & 4 \\
12 & Geomorphic Mapping & Mapping & Geological & Watershed & 2004 & NA \\
13 & Understory Evapotranspiration & Point & Hydrological & Plot & 2018 & 1 \\
14 & Fog Dynamics & Continuous & Hydrological & Plot & 2020 & 2 \\
15 & Vegetation Recovery & Point, Repeated & Biological & Plot & 2019 & $20+$ \\
\hline
\end{tabular}

*Anticipated length of study period

a2006-2008 and 2019-2021

FIGURE 2 | Conceptual study diagram depicting approximate spatial representation of 15 studies associated with the Third Experiment. Study numbers and descriptions are located in the table. Arrows represent the following (not to scale): blue, hydrologic fluxes; green, nutrient fluxes; brown, sediment fluxes.

hydrologic variables. The paired watersheds are monitored in their unaltered state during a "calibration" period, with the intent of capturing typical climatic variability. During the calibration period, a relationship is developed between streamflow (or other metric) in one watershed (the "control" watershed) and relative to the second watershed (the "treatment" watershed). Following the calibration period, an experimental treatment is applied to the treatment watershed. This treatment can include forest harvesting, reforestation, herbicide application, prescribed fire, road building or road removal, removal of beaver dams, or other management objectives. The response variable is monitored in both watersheds during the post-treatment period, often for five or more years. The paired watershed approach is often also called a Before-After-Control-Impact, or BACI, design, as the sites are monitored both before and after a treatment, and control and impacted sites are studied.

The paired watershed approach typically utilizes a regression model (for discrete observations) or double-mass curve (for cumulative data) to determine the impact of a treatment on the response variable. As mentioned above, a calibration relationship is developed between the control watershed (the independent variable) and the treatment watershed (the dependent variable) for the pre-treatment or calibration period. Following the treatment, the departure of the response variable from the values predicted using the calibration relationship is used to assess treatment effects. This analysis and visualization can be done in several ways. An analysis of covariance, or ANCOVA, can be used to test for differences in slope between the watershed pairs pre- and post-treatment. In some cases, a bivariate plot of the pre-treatment and post-treatment regression lines can be used to visualize the changes following the treatment. In other cases, deviations, or departures, from the original calibration relationship are presented instead of regression lines, as this gives a visual representation of how the response variable changes over time with the treatment. For double-mass curve approaches, the cumulative data for the calibration and treatment periods are 
plotted and a slope break is an indication of a treatment effect. For more information on double-mass curves and ANCOVA as it applies to paired-watershed studies, see Searcy and Hardison (1960) and Clausen and Spooner (1993), respectively.

\section{Overview of the Design of the Third Experiment}

In 2000, gaging stations were installed to monitor streamflow and sediment in ten sub-watersheds within the South Fork Caspar Creek in preparation for the Third Experiment. In addition to the South Fork weir, two gages are located along the main stem and eight gages are located at sub-watershed outlets (Figure 3 and Table 1). Streamflow and turbidity at nine of the stations are recorded with electronic data loggers at 10min intervals using Montana flumes equipped with pressure transducers and turbidimeters. These data are often not recorded during the dry season when flows are too low to be gaged accurately. Sub-watershed ZIE is nested within YOC, which captures cumulative watershed impacts at the downstream YOC gauge. An additional sub-watershed, QUE, is located on the lower South Fork mainstem and discharge is calculated by subtracting OGI discharge from discharge at the South Fork weir. Suspended sediment samples are collected at predetermined turbidity thresholds for each station using pumping samplers triggered with a turbidity threshold sampling protocol (TTS; Lewis and Eads, 2009). Water samples are measured for SSC using gravimetric methods.
The Third Experiment was designed to discern potential thresholds at which harvesting begins to affect watershed processes using a range of harvesting intensities. Thus, a regression-based design will enable us to capture a broad range of harvesting treatment levels (Table 1). Target harvest treatment levels across six treatment sub-watersheds ranged from 25 to $75 \%$ reduction in pre-treatment basal area, with two no-treatment sub-watersheds established as experimental controls (see section "Selecting Control and Treatment Watersheds," below).

\section{Selecting Control and Treatment Watersheds}

Two important questions when designing a paired watershed study are (a) What is the ideal number of control watersheds? and (b) Which watersheds should be treated and which should serve as controls? In this section, we discuss how these questions were addressed and informed the design of the Third Experiment.

The Second Experiment had illustrated the importance of having multiple controls. Three control sub-watersheds in the North Fork experiment made it possible to compensate for occasional missing records, which more-often occurred during large, less-frequent storms. In addition, the use of multiple controls made it possible to assess the variability in the control watersheds and identify anomalous behavior. Before the specific number of control sub-watersheds could be chosen for the Third Experiment, the suitability of each sub-watershed in the South Fork to serve as a control was assessed.

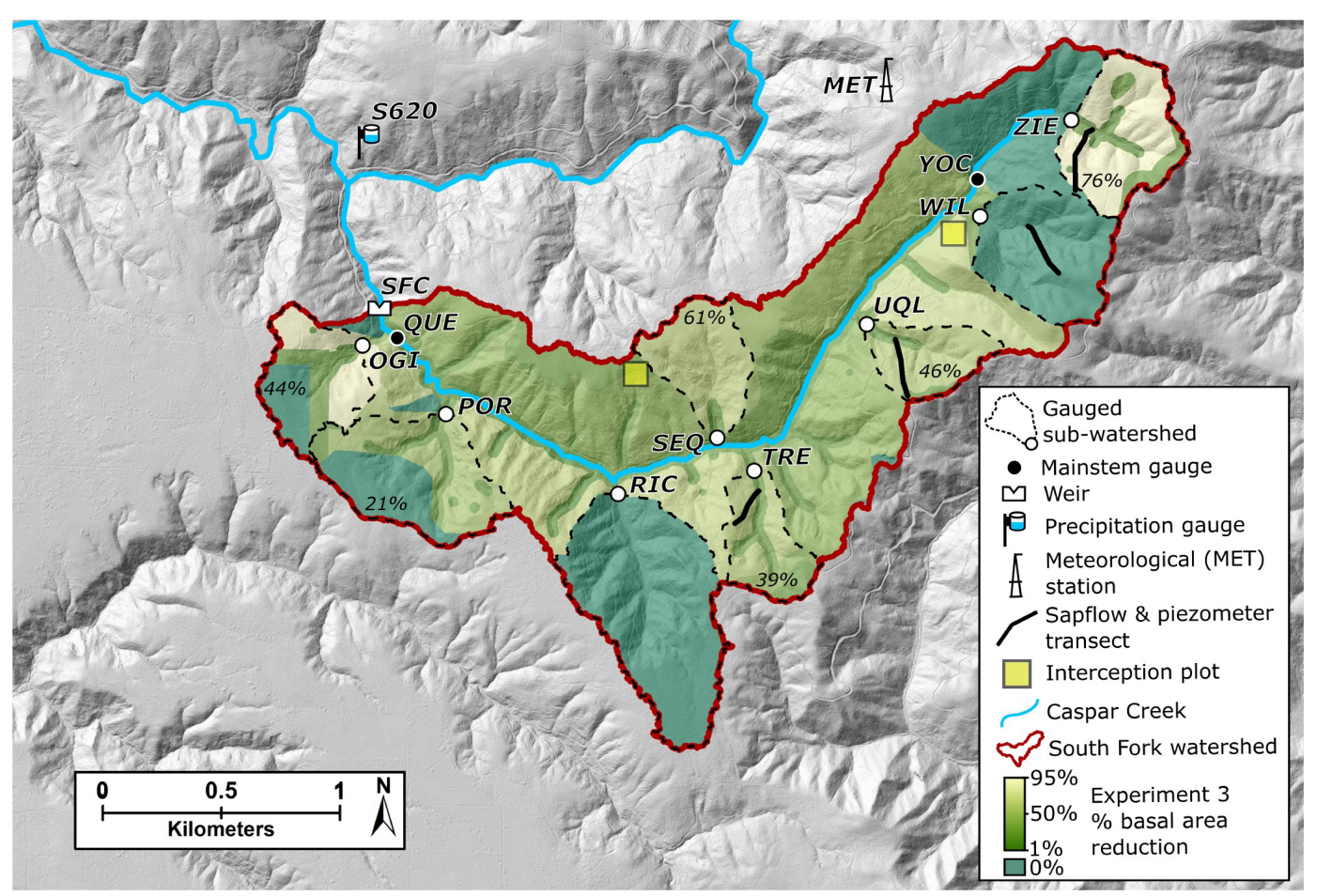

FIGURE 3 | Shaded relief map of the South Fork watershed showing study locations and harvest results for the Third Experiment. Mean percentage of basal area reduction from the timber harvest is noted for harvested, gaged sub-watersheds. The shaded relief map was created from LiDAR data collected in 2017 gridded to 1-m horizontal resolution. 
TABLE 1 | Landscape features of the sub-watersheds in the South Fork of Caspar Creek.

\begin{tabular}{|c|c|c|c|c|c|}
\hline Name & Area (ha) & Elevation range $(\mathrm{m})$ & Average slope (\%) & Target harvest (\%) & Dominant soil subgroup(s) \\
\hline Ogilvie (OGl) & 19 & $58-174$ & 26.3 & 45 & Mollic/Ultic hapludalf \\
\hline Porter (POR) & 31 & $61-186$ & 34.2 & 25 & Ultic hapludalf \\
\hline Quetelet (QUE) & 392 & 48-329 & 49.8 & 35 & Mollic/Ultic hapludalf \\
\hline Richards (RIC) & 47 & $73-198$ & 41.6 & 0 & Mollic/Ultic hapludalf \\
\hline Sequoyah (SEQ) & 17 & 79-207 & 37.9 & 65 & Ultic hapludalf \\
\hline Treat (TRE) & 14 & $98-244$ & 46.5 & 35 & Mollic/Ultic hapludalf \\
\hline Uqlidisi (UQL) & 13 & $122-323$ & 48.5 & 55 & Typic haplohumult \\
\hline Williams (WIL) & 26 & $146-323$ & 50.5 & 0 & Typic haplohumult \\
\hline Yocom (YOC) & 52 & $146-329$ & 47.5 & $0^{\mathrm{a}}$ & Typic haplohumult \\
\hline Ziemer (ZIE) & 24 & 213-329 & 43 & 75 & Typic haplohumult \\
\hline South Fork (SFC) & 417 & 46-329 & 59.6 & 35 & Ultic hapludalf \\
\hline
\end{tabular}

a Target harvest of the area downstream of ZIE gauge. The YOC sub-watershed includes ZIE.

TABLE 2 | Suitability of the South Fork sub-watersheds as control or treatment sub-watersheds.

\begin{tabular}{|c|c|c|c|c|}
\hline \multirow[t]{2}{*}{ Gauge } & \multirow{2}{*}{$\begin{array}{l}\text { Area } \\
\text { (ha) }\end{array}$} & \multicolumn{2}{|c|}{ Suitability } & \multirow[t]{2}{*}{ Considerations } \\
\hline & & Control & Treatment & \\
\hline Ogilvie (OGl) & 19 & No & Yes & Inconsistent sediment response; low correlation to others; private land in headwaters \\
\hline Porter (POR) & 31 & No & Yes & Highest sediment loads; greatest road-fill volume at risk; State Park land in headwaters \\
\hline Richards (RIC) & 47 & Yes & Yes & Includes mushroom management area \\
\hline Sequoyah (SEQ) & 17 & No & Yes & Only gaged sub-watershed with south aspect \\
\hline Treat (TRE) & 14 & No & Yes & Small size \\
\hline Uqlidisi (UQL) & 13 & No & Yes & Recent slide \\
\hline Williams (WIL) & 26 & Yes & Yes & Consistent response; highest correlations to other sub-watersheds \\
\hline Yocom (YOC) $)^{\mathrm{a}}$ & 52 & No & No & Downstream and inclusive of ZIE \\
\hline Ziemer (ZIE) & 24 & No & Yes & Opportunity to monitor effects of upstream activity \\
\hline
\end{tabular}

Final experimental designators are bold.

alncludes the nested area of ZIE. Therefore, it is neither an independent treatment nor control sub-watershed in this study design.

We considered several issues in the suitability assessment of control sub-watersheds. In particular, they must be capable of reliably contributing the data needed to assess the treatment effects on streamflow and sediment delivery in the harvested subwatersheds. For storm-based analysis, this requirement meant that a control sub-watershed's response to storms should be relatively scaled to the size of storms and that the responses during the calibration period should be well-correlated to responses in the sub-watersheds targeted for treatment. Also, sub-watersheds that have recently experienced large erosion events, such as gullying and landslides, are less suitable. Further, the responses in the control sub-watersheds need to be comparable to those in the sub-watersheds to be treated with respect to magnitude and pattern. For example, it was deemed essential that both control and treatment sub-watersheds respond to the same storm events and proportionately respond to larger precipitation events, although it was not necessary for the subwatersheds to produce the same relative increases in peak flows to storm events.

Initial analyses of OGI and POR made them less attractive as controls because they were not entirely under JDSF jurisdiction (Figure 3 and Table 2). OGI was also poorly correlated to the other sub-watersheds for both peak flows and sediment loads, reducing its potential utility as a predictor (Supplementary Table 1). POR had the highest unit-area suspended sediment yield and the largest volume of in situ and road-fill per unit area. Although POR had high correlations to the other sub-watersheds, it was deemed unsuitable as a control because these factors.

We also ruled out several sub-watersheds as controls because of other factors (Table 2). UQL was poorly suited as a control because of a major landslide in March 2006 that required a flume replacement. SEQ is the only north-facing gaged subwatershed in the South Fork, and concerns about the aspect's influence on the bedding plane orientation, an important factor in slope stability, made it poorly suited as a control. YOC is located downstream of ZIE, so it could only serve as a control if ZIE was also selected as a control. Lastly, TRE has the second smallest drainage area of the sub-watersheds, making sediment loads relatively sensitive to discrete events such as landslides, and was not selected as a control despite its relatively high correlations to other sub-watersheds (Supplementary Table 1).

In the end, we determined that WIL and RIC would make suitable controls and provide the minimum redundancy. Storm peak flows and sediment loads for both WIL and RIC were well-correlated with those of other sub-watersheds (Supplementary Table 1), had lower variance in mean unitarea sediment loads than TRE, and did not have the longterm management concerns of POR. Additionally, RIC and WIL represent two major soil orders present in the watershed (Alfisols 
and Ultisols, respectively) and thus together better captured heterogeneity in landscape pedology. The decision to select WIL and RIC as controls was further supported by the observation that neighboring sub-watersheds exhibited similar storm responses, so there was a preference for selecting controls that were not adjacent to one another (Figure 3 and Supplementary Table 1). The peak flows for the sub-watersheds targeted for treatment relative to these two control sub-watersheds are shown in Figure 4.

Because vegetation exerts such a strong control over hydrologic and geologic dynamics in paired-watershed studies, the pre- and post-treatment vegetation is also extremely important to consider. The overstory composition at Caspar Creek is relatively homogenous compared to many other watersheds, with no major trends in species composition across aspects or elevation gradients. Overstory inventory of the sub-watersheds at Caspar Creek (species and basal area) was conducted by JDSF staff pre- and post-harvest (Table 3), and will continue to be monitored as the sub-watersheds recover from harvesting. As the vegetation at other field sites may vary from sub-watershed to sub-watershed, the overstory composition must be carefully considered prior to undertaking a paired-watershed experiment. Furthermore, plant species respond to and recover from disturbance differently, so their differential responses must be considered and accounted for in post-treatment analysis.

Once the control sub-watersheds were identified, the treatment levels were randomly assigned but subject to modifications as described in Section "Real-World Limitations of Harvesting Experiments." The higher harvest rates were designed to push the systems beyond typical uneven-aged stand management to identify thresholds at which hydrologic and ecological function of the watersheds might be stressed. The variability in harvest could serve as a resource for exploring economic and environmental consequences of more intensive harvesting. The "matrix" area between the sub-watersheds was targeted to be harvested at a moderate intensity (averaging approximately 35\%), producing downstream effects that combine with the effects of the treatments in the sub-watersheds. Streamflow, sediment yield, and turbidity levels associated with harvesting from both the matrix area and sub-watersheds are recorded at stations located on the mainstem of the South Fork, including at the SFC weir pond for bedload measurement (Figure 3).

\section{Real-World Limitations of Harvesting Experiments}

An additional consideration in selecting a control or treatment watershed is the operational constraint that might be imparted by its prior history, current use, or adjacency to areas with special management concerns. In the Third Experiment, treatment designation of three of the sub-watersheds fell into this category due to multiple ownerships and JDSF management plan direction, proximity to renowned mushroom study areas, and adjacency to habitat for marbled murrelet [Brachyramphus marmoratus (Gmelin)], a state and federally listed bird. Additionally, one of the study sub-watersheds (OGI) contained a 0.06 -ha reservoir in its privately owned headwaters, with about 4 ha $(21 \%)$ of watershed upstream of the reservoir. When conducting a paired watershed study, it is critical that
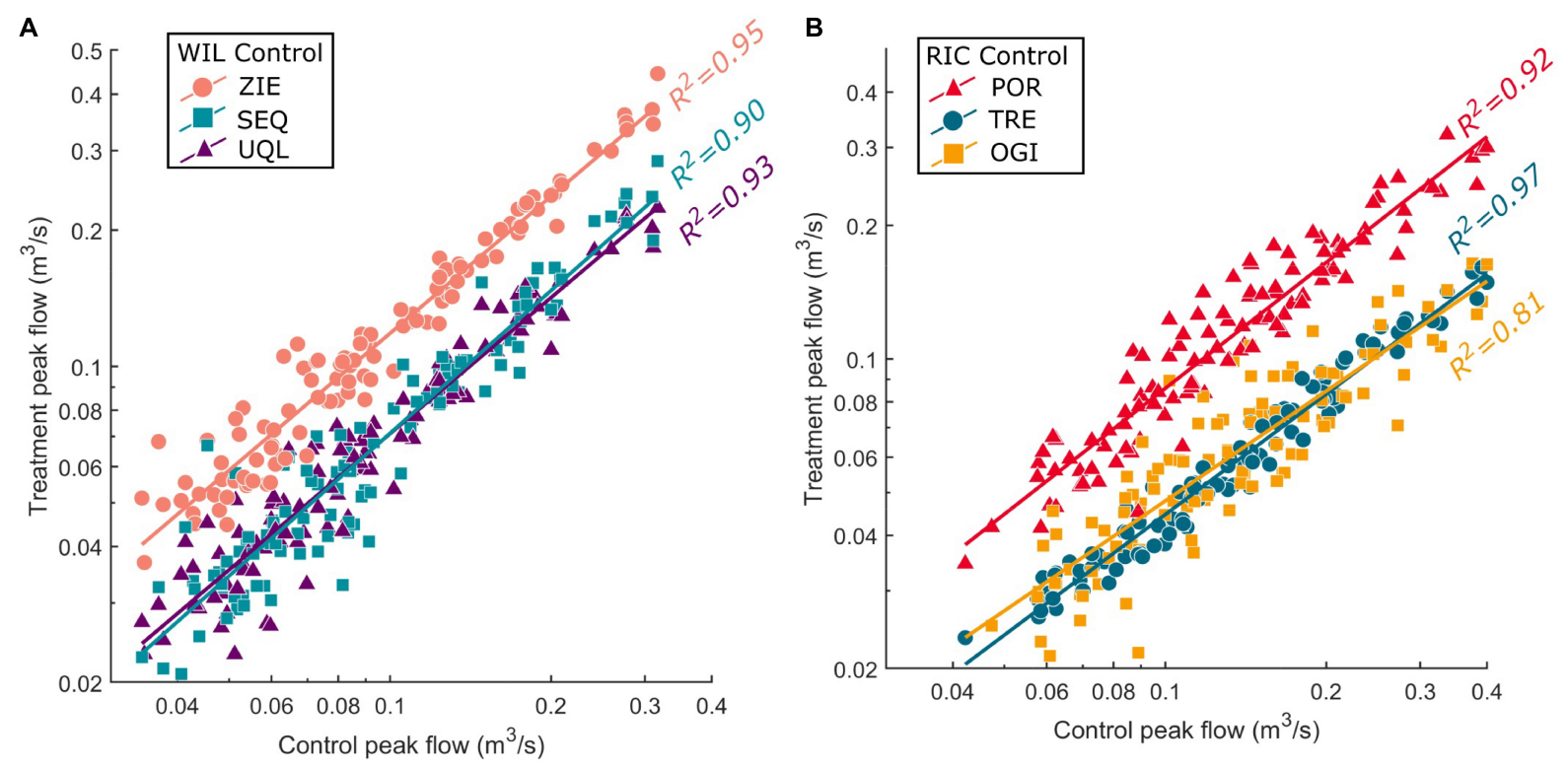

FIGURE 4 | Peak flow calibration period relationships between (A) the treatment sub-watersheds ZIE, SEQ, and UQL and the control sub-watershed WIL and (B) the treatment sub-watersheds POR, TRE, and OGI and the control sub-watershed RIC. For storms with multiple peaks, the peaks were chronologically matched across stations and the highest peak at the majority of stations was identified as the peak flow. Peak flows below $0.02 \mathrm{~m}^{3} / \mathrm{s}$ were excluded from the analysis and the data were log transformed. The best-fit line from ordinary least squares regression analysis of the log-transformed data for each control-treatment pair is shown, and the corresponding $R^{2}$ value is listed next to the regression line. Regression equation coefficients are included in Supplementary Table 2. 
TABLE 3 | Sub-watershed and SFC areas, treatment target basal area (BA) reduction rates, pre- and post-harvest basal areas, and area-weighted percent basal area reductions.

\begin{tabular}{|c|c|c|c|c|c|}
\hline & Area (ha) & Target BA Removal (\%) & Pre-harvest BA (m²/ha) & Post-harvest BA (m ${ }^{2} /$ ha) & BA Reduction (\%) \\
\hline \multicolumn{6}{|l|}{ Gaged Sub-watersheds } \\
\hline Ogilvie (OGI) & 19 & 45 & 75 & 42 & 44 \\
\hline Porter (POR) & 31 & 25 & 79 & 63 & 20 \\
\hline Quetelet (QUE) ${ }^{\mathrm{a}}$ & 192 & NA & 84 & 50 & 41 \\
\hline Richards (RIC) & 47 & 0 & 87 & 87 & 0 \\
\hline Sequoyah (SEQ) & 17 & 65 & 95 & 38 & 61 \\
\hline Treat (TRE) & 14 & 35 & 94 & 56 & 40 \\
\hline Uqlidisi (UQL) & 13 & 55 & 78 & 41 & 47 \\
\hline Williams (WIL) & 26 & 0 & 99 & 99 & 0 \\
\hline Yocom (YOC) $)^{a}$ & 28 & 0 & 90 & 90 & 0 \\
\hline Ziemer (ZIE) & 24 & 75 & 86 & 21 & 76 \\
\hline South Fork $(\mathrm{SFC})^{\mathrm{a}}$ & 6 & NA & 93 & 64 & 32 \\
\hline \multicolumn{6}{|l|}{ Main Stem Gauges } \\
\hline Above YOC Gauge & 52 & 35 & 88 & 58 & 34 \\
\hline Above QUE Gauge & 392 & NA & 86 & 59 & 31 \\
\hline South Fork (SFC) & 417 & NA & 86 & 58 & 32 \\
\hline
\end{tabular}

NA indicates there was not a specific target stand density reduction for these areas.

${ }^{a}$ Excludes areas identified for upstream sub-watersheds.

researchers fully assess the potential limitations in pairing prior to choosing and treating the study sites to avoid introducing bias or confounding factors that might invalidate the experiment. To accommodate the potential issues identified above, the harvest intensities for OGI and POR, whose initial target harvest rates were 25 and $45 \%$, respectively, were exchanged prior to treatment, resulting in the treatment design shown in Table $\mathbf{1 .}$ While this violated the assumption of independence of the randomized treatment assignment, we think the slight loss in independence was justified by the ability to actually meet the modified target treatment rates and maintain the overall experimental design.

\section{ASSOCIATED STUDIES OF THE THIRD EXPERIMENT}

While paired watershed studies are often designed with a specific goal, the experimental design often allows for a multitude of additional research questions to be addressed. Because of the large investments in planning, personnel, and equipment associated with the Third Experiment, care and effort were taken to explore as many research questions as possible (Figure 2). We briefly detail the studies associated with the Third Experiment below. Some of these projects began prior to the experimental harvests, while others began post-treatment with the goal of evaluating post-harvest recovery. Additionally, some projects are completed or nearing completion, while others are anticipated to continue for years.

\section{Watershed Resilience and Recovery Study}

Myriad studies have investigated the role of vegetation removal on streamflow and sediment yield (Hibbert, 1967; Stednick, 1996; Lewis et al., 2001; Karwan et al., 2007; Keppeler et al., 2009).
However, few studies have linked watershed processes to the intensity of stand density reduction in a single site, especially in previously harvested watersheds. Determining the relationships between stand density reduction and streamflow and sediment yield across a range of intensities will allow managers to identify thresholds at which reducing stand density may begin to affect watershed processes. The goal of the watershed resilience and recovery study is to quantify the effect of different levels of canopy removal on streamflow and sediment yield in the South Fork Caspar Creek under updated CFPRs. Specifically, this study is addressing the following research questions:

1) How does stand density reduction influence annual streamflow (i.e., water yield), peak flows, low flows, turbidity, and sediment yields?

2) Is there a detectable threshold at which stand density reduction begins to influence streamflows, peak flows, low flows, turbidity, and sediment yields?

3) How does stand density reduction influence the responses of streamflow, peak flows, low flows, turbidity, and sediment yields during the recovery period?

4) Does the stand density reduction intensity affect the time it takes streamflow, peak flows, low flows, turbidity, and sediment yields to recover to pre-harvest conditions?

Streamflow, turbidity, and SSC have been measured at the South Fork sub-watershed gaging stations (Figure 3) since 2000, except during summer dry periods when streamflow is below the detection of the flumes. These data will continue to be collected throughout the post-treatment period in order to track the initial responses and recovery of the sub-watersheds following timber harvest treatments and, in some of the sub-watersheds (Supplementary Figure 1), temporary and permanent road use. 


\section{Plant-Soil-Water Dynamics Study}

It is increasingly critical to improve our understanding of how forest disturbances affect the storage and release of water throughout watersheds (McDonnell et al., 2018), particularly in seasonally dry Mediterranean climates (Tague et al., 2019). Further, it is not yet understood how disturbances impact water compartmentalization at time scales other than the annual water balance. Here, we hypothesized that the ecohydrological response of a forested watershed is proportional to the severity of disturbance. We selected four of the sub-watersheds (WIL, TRE, UQL, and ZIE) with target harvest intensities of $0,35,55$, and $75 \%$, respectively (Figure 3) to investigate the following research questions:

1) What are the annual, seasonal, and diurnal variations and patterns of precipitation, fog, transpiration, evaporation, soil moisture, groundwater, and stream discharge in coast redwood forests?

2) How do soil moisture, stream discharge, groundwater, and transpiration respond to precipitation events in these systems?

3) How do different levels of timber harvest change the patterns, magnitudes, and variations of soil moisture, stream discharge, groundwater, and transpiration compared to pre-harvest conditions?

4) Does hillslope position between the stream channel and the ridgeline affect the patterns of soil moisture, groundwater, or transpiration?

In 2015-2016, we installed instrumented transects in the four sub-watersheds (Figure 3), allowing us to assess the relationships between harvest intensity and different hydrologic components. Transpiration, soil moisture, groundwater, and photosynthetically active radiation (PAR) are measured at five topographic positions along each of the four transects, while air temperature and relative humidity are measured at a subset of these positions. This study is ongoing, with measurements continuing at least through 2021.

\section{Water Worlds Study}

It was traditionally believed that water movement along a hillslope followed the theory of translatory flow, where precipitation entering the soil displaces the water that is currently present in the soil, which displaces the older water further into the soil profile and so on eventually to the stream (Pearce et al., 1986). New research, however, has suggested the existence of "two water worlds," whereby soil water does not mix with precipitation (Brooks et al., 2010). It is unknown whether timber harvest activities alter subsurface flow processes enough to enhance or eliminate mixing of subsurface water pools. The primary objectives of this study are to improve the mechanistic understanding of how timber harvesting influences (a) the delivery of water from hillslopes to streams, and (b) water use by the remaining trees. Specifically, this study was designed to address the following questions:

1) How does timber harvesting affect hydrologic connectivity across the upslope-riparian-stream continuum, thereby influencing the hydrologic response of a watershed to precipitation events?

2) How does the residence time of water in a watershed change following timber harvest?

3) Do the residual trees change their source of water for transpiration following harvest of adjacent trees?

A dual isotope $\left(\delta^{2} \mathrm{H}, \delta^{18} \mathrm{O}\right)$ approach is being used to compare water samples from soil, groundwater, streamflow, and plants before and after harvesting across the gradient of harvest intensities in WIL, TRE, UQL, and ZIE (Table 1). This approach allows an investigation of the influence of timber harvesting on the "two water worlds": (a) the tightly bound water used by trees, and (b) the mobile water related to infiltration, groundwater recharge, hillslope runoff, and streamflow. Seasonal water samples are collected from groundwater, soil water, xylem water, streamflow, precipitation, and fog and analyzed for $\delta^{2} \mathrm{H}$ and $\delta^{18} \mathrm{O}$. Sampling began in 2015 and will continue at least through 2021.

\section{Bioassessment Study}

California's natural resource agencies have begun prioritizing ecological performance measures to evaluate resource management objectives and support regulatory policies. To measure the ecological integrity of streams, California agencies use standardized bioassessment protocols (Ode et al., 2016a), which compare measurements of biological, physical and chemical conditions at sampled stream reaches to reference conditions (Ode et al., 2016b). These procedures were developed by the California Department of Fish and Wildlife (CDFW) and the State Water Board's Surface Water Ambient Monitoring Program (SWAMP), based on protocols developed for U.S. EPA's National Aquatic Resource Surveys (US EPA, 2017), and have been the primary method for evaluating stream health throughout California since 2006 (Ode et al., 2011). This study is evaluating the response of benthic invertebrate communities to stand density reductions, with three main objectives:

1) Establish current conditions of biological integrity for the streams draining the South Fork of Caspar Creek.

2) Evaluate the variability of bioassessment data in the mainstem of the South Fork and sub-watersheds, and potential associations with harvest intensity.

3) Develop recommendations for future bioassessment monitoring in the Caspar Creek Experimental Watersheds.

Sampling sites were established at nine locations in the South Fork: six in the mainstem upstream and downstream of the confluences of the POR, SEQ, and RIC sub-watersheds, and three within these tributaries. All sample locations have been permanently monumented to help field crews locate the exact stream site for future monitoring events. The SWAMP bioassessment protocols were used to collect data on the benthic invertebrate communities, water chemistry and physical attributes of each site, including characteristics of the instream (e.g., substrate composition, flow and microhabitat diversity, slope and sinuosity) and riparian (e.g., vegetative complexity, canopy cover, invasive species) habitat. Biological and chemical 
samples are being processed by CDFW staff using standard taxonomic procedures (Woodard et al., 2012). All sites were sampled in spring/early summer of 2016 and 2017 before timber harvest and at the same time after harvest in 2018 and 2019, with a final sampling planned for spring 2021. Sampling is conducted by trained personnel from CAL FIRE and the USFS PSW. A report of findings will be completed by June 2022 to determine current conditions and make recommendations for future sampling.

\section{Hydrologic and Suspended Sediment Effects of Forest Roads}

Forest roads create significant hydrologic disturbance and are a source of sediment in forested watersheds (Motha et al., 2003; Croke and Hairsine, 2006; Sosa-Pérez and MacDonald, 2016). Forest road networks present a high potential for increased surface runoff and hydrologic connectivity to streams, and as a result, high sediment delivery risk potential, in comparison to undisturbed forest areas (e.g., Wemple et al., 1996; Zemke, 2016; Kastridis, 2020). The construction and use of forest roads have evolved over time as forest practices improved. However, many mountain watersheds still have elements of legacy road networks with ineffective designs for modern transportation and environmental impacts.

This study examined the hydrologic influence of a modern and legacy road network on sediment delivery and cumulative watershed effects in the Third Experiment (Surfleet, 2020; Surfleet and Marks, in review). Peak runoff was measured on 17 road segments, and runoff, turbidity, and suspended sediment on six road segments in the first winter following the timber harvest in the gaged sub-watersheds (2018-2019). We used road runoff and sediment measurements to evaluate physical road dimensions, turbidity, and road runoff for prediction of road suspended sediment yield. The Distributed Hydrology Soil and Vegetation Model (DHSVM) (Wigmosta et al., 1994) was calibrated to streamflow and road runoff to examine the hydrologic and sediment effects for the modern-design (2018) road network, located high on slopes away from watercourses and the First Experiment (pre-1974) road network, where roads were near stream channels with more watercourse crossings and streamside impact. DHSVM was then used to simulate the effect on peak flows and suspended sediment for different road management scenarios associated with changes in the road practices.

Surfleet and Marks (in review) found a statistically significant relationship between road peak flow, peak turbidity, road cutslope cover, and road surface type (rocked or native) with suspended sediment loads from roads $(p<0.001$; $\left.R^{2}=0.86\right)$. When evaluating only the road dimensions and event precipitation (no measured runoff) on suspended sediment load from roads, the road length times slope squared, road surface type, and cutslope height provided the best statistical predictors ( $p$-value $\left.<0.001 ; R^{2}=0.81\right)$ (Surfleet and Marks, in review).

The modeling results showed that modern road designs that reduce watercourse crossings and include frequent road drainage to achieve hydrologic disconnection of the roads and streams significantly decreased road runoff and suspended sediment contributions. The study demonstrated the utility of using a hydrologic model to provide spatial extrapolation of a few road runoff and suspended sediment measurements to answer largerscale questions. It suggests that models that can predict the hydrologic response from forest roads can be used to influence design and management of road networks. This study was completed in June 2020.

\section{Effect of Streamside Buffers on Modeled Stream Temperatures Associated With Forest Harvest}

It is commonly accepted that the removal of over-stream tree canopy during forest harvesting increases stream temperatures (e.g., Brown and Krygier, 1970; Beschta et al., 1987; Johnson and Jones, 2000; Carroll et al., 2004). Yet there is still considerable debate regarding how individual processes amalgamate to affect stream temperature (Dugdale et al., 2017) and of the size and structure of streamside buffers needed to mitigate changes in water temperature after forest harvesting. This study aimed to better understand the efficacy of the CFPRs' streamside buffers (Watercourse and Lake Protection Zones) regulations at mitigating impacts on stream temperature using the coupled DHSVM and the River Basin Model (DHSVM-RBM) (Ridgeway, 2019). This study quantified changes in stream temperature under different simulated streamside buffer scenarios by varying the size and structure of shade canopies. The scenarios emulated the forest harvest plan of the Third Experiment (Table 1) and an alternative experimental design scenario that converted the dominant riparian vegetative species. We also addressed the potential impacts of future climate conditions by running the DHSVM-RBM model with climate data from a warmer location to assess potential impacts to stream temperatures if considerably warmer air temperatures and lower relative humidity values occur.

The study showed that selective forest harvest, with streamside buffers at the $80 \%$ canopy cover as required by the CFPRs in areas with listed anadromous salmonids, resulted in little change in average or maximum stream temperatures (Ridgeway and Surfleet, 2021). Overall, these findings support the work of other studies stressing the importance of riparian vegetation in moderating stream temperatures. Our sensitivity analyses further suggest that maintaining tall, dense buffers are more effective at maintaining stream temperature than wider buffer widths.

\section{Sediment Fingerprinting Study}

Forest harvesting operations in headwater watersheds have often resulted in increased SSCs and yields in first, second, and third order streams (Beschta, 1978; Reid and Dunne, 1984; Grayson et al., 1993). However, forest management practices have changed rapidly, including the size and harvest operation restrictions of buffers around water bodies, reduced clearcut sizes, harvest operations on steep slopes, advances in technology of machinery, and modified road construction and maintenance activities. As such, many questions remain about the effectiveness of current best management practices (BMPs) at mitigating suspended sediment delivery to streams (Cristan et al., 2016). 
Some of the uncertainty about BMP effectiveness is due to the many challenges associated with identifying the sources of in-stream suspended sediment (Collins and Walling, 2002). In recent years, sediment fingerprinting techniques have been used to determine temporally and spatially constrain the sources of sediment (Walling, 2005; Collins et al., 2010). The techniques rely on quantifying unique physical or chemical properties of sediment and attributing those to distinct sources (Collins and Walling, 2004). Identifying the most prevalent sources of sediment in streams will help forest managers target best management practices to mitigate downstream sediment delivery. As such, the goals of this study were to:

1) determine the source of sediments in the sub-watersheds of South Fork Caspar Creek using geochemical fingerprinting techniques;

2) investigate how different levels of stand density reduction influence the source of sediment in this stream system.

We collected soil or sediment samples prior to timber harvesting in eight of the South Fork's sub-watersheds from potential source locations including (a) uneroded hillslopes, (b) streambanks, (c) roads, and (d) channel beds. We collected soils by horizon, including the $\mathrm{O}$ horizon, using a shovel and auger down to $50 \mathrm{~cm}$ or the $\mathrm{C}$ horizon, whichever occurred first. Samples from the streambanks and roads were collected with a hand trowel by scraping exposed surfaces from the top of the surface. Fine sediment stored within the streambed was collected using a freeze-core method. All samples were placed in WhirlPak bags and refrigerated until processing and chemical analyses were completed.

We also collected in-stream sediment samples by deploying a network of time-integrated Phillips samplers (Phillips et al., 2000) near the sub-watershed outlets. We constructed the Phillips samplers with $4 \mathrm{~mm}$ diameter inlet and outlet tubes, and a $1 \mathrm{~m}$ length of PVC pipe with a $98 \mathrm{~mm}$ inside diameter. Sediment from these samplers was collected approximately six times through each of two wet seasons (ending spring 2017 and 2018). Dried glass fiber filters used in the gravimetric determination of SSC in water samples from the sub-watershed gaging stations during this period were also used in the analyses that could be done on a small sample mass.

All of the source samples were analyzed to identify a unique chemical fingerprint for each source area, which was necessary to enable the use of a mixing model to quantify the proportions of each source in the suspended sediment samples. To do this, we analyzed the time-integrated samples for (a) total carbon (TC) and total nitrogen (TN) concentrations, (b) stable isotopes of nitrogen $(\delta 15 \mathrm{~N})$ and carbon $(\delta 13 \mathrm{C}),(\mathrm{c})$ iron $(\mathrm{Fe})$, potassium $(\mathrm{K})$, and calcium $(\mathrm{Ca})$ geochemistry, (d) magnetic susceptibility, and (e) grain size. The glass fiber filters were analyzed for carbon and nitrogen and their isotopes. Those parameters that successfully distinguish between at least two or more endmembers will then be applied to all suspended sediment samples. Using the resulting set of parameters, the composition of the sediment and source materials will be entered into a multivariate mixing model to determine the contribution of each source to the in-stream suspended sediment composition. Identification of the sources of in-stream suspended sediment will enable us to assess the effectiveness of current BMPs at mitigating sediment transport to streams. A final report will be produced by the summer of 2021 .

\section{Fine Sediment Study}

A large body of evidence has shown that historic forest management practices substantially increased fine sediment delivery to streams (Beschta, 1978; Reid and Dunne, 1984; Bilby et al., 1989). As a result, current forest management has been designed to mitigate sediment delivery and minimize negative effects on aquatic and riparian ecosystems. Sediment delivery to streams under contemporary forest management can be very different from what was documented in past studies of historical management practices (Loehle et al., 2014; Arismendi et al., 2017). However, little is known about the consistency of fine sediment transport among neighboring watersheds, leaving questions about how sediment transport in streams varies spatially and temporally under contemporary forest management. For example, watersheds with high natural variability of in-stream sediment inputs under baseline conditions add to the difficulty in identifying the contribution of contemporary forest management to sediment rates. In addition, the characterization of fine sediment delivery to streams has been limited to the use of simple central tendency metrics (e.g., mean and median). These metrics cannot provide insights about the fine sediment regime of streams including the frequency, duration, or timing of events (daily, weekly, or seasonal). The frequency and duration of extreme events of fine sediment delivery can inform managers about impacts of contemporary forest management on aquatic ecosystems, as these metrics describe the exposure of instream biota to potential stressors.

The goal of this study is to apply novel descriptors of hydrological events to suspended sediment data collected from the Second and Third Experiments at the Caspar Creek Experimental Watersheds. The specific research objectives are to:

1) Evaluate and apply previously developed descriptors of fine suspended sediment regimes (Diehl and Wolfe, 2010; Arismendi et al., 2013, 2015) to the long-term datasets available from Caspar Creek.

2) Contrast fine suspended sediment regimes within subwatersheds and between the South Fork and North Fork of Caspar Creek.

3) Evaluate the utility of these descriptors as ecological indicators of environmental impacts of contemporary forest management.

Specifically, we are evaluating and contrasting forest management practices from the Second Experiment in the North Fork with the Third Experiment in the South Fork by using two novel statistical techniques: the magnitude-magnitude plot and the magnitude-duration plot. The magnitude-magnitude plot (Figure 5A) contrasts the average SSC of a storm that exceeds a given threshold. In addition, we are using a magnitude-duration plot (Figure 5B) proposed by Diehl and Wolfe (2010) and 
modified to use several thresholds based on quantiles rather than absolute values. To define biologically relevant thresholds, we are adopting the MODEL 3 set of thresholds that focus on salmonid responses (Diehl and Wolfe, 2010) including avoidance, moderate physiological stress, and reduced growth rate. In our illustrative example (Figure 5B), there was an apparent shift in the suspended sediment regime after forest harvest, but the shift was insufficient to produce a moderate physiological stress on salmonid populations represented by the dotted black line.

\section{Road Rehabilitation Study Section}

The effects of legacy roads and abandoned skid trails on erosion and sedimentation remain of critical concern to forest managers and regulatory interests. Measures to mitigate road erosion may result in short-term increases in sediment in order to achieve long-term benefits, but these trade-offs are not well-documented. The increased use of "stewardship contracts" by U.S. National Forests in recent years has led to an increase in the amount of road rehabilitation that is done at about the same time as timber harvests. This study assesses the impacts of road rehabilitation treatments when performed either in advance of, separate from, or coincident with timber harvest. Research questions are:

1) What are the erosional effects of road rehabilitation treatments done in the absence of harvest as compared to rehabilitation done in association with timber harvest?

2) Is there a difference in the erosional effects of road rehabilitation when done coincident with timber harvest as compared to prior to harvest?

3) What is the magnitude and duration of road rehabilitation treatment effects on downstream water quality?

The study site is a $4.6 \mathrm{~km}$ mid-slope road constructed in 1973 and traversing UQL, WIL, YOC, and ZIE
(Supplementary Figure 1 and Table 4). Treatments consisted of fill removal and road drainage improvements and were completed in 2011 (YOC and ZIE) and 2019 (UQL). Pretreatment surveys documented road and channel dimensions, drainage diversions, and erosion features. Cross-sections and longitudinal profiles were established at 22 stream crossings including the no-treatment controls in WIL. Sites were resurveyed after treatment and during subsequent winters. In addition, suspended sediment loads measured at the downstream gaging stations will be compared to on-site erosion measurements. Re-measurement after peak flows with recurrence intervals of at least 2 years will continue through 2022.

\section{Nutrient Study}

Although there is general agreement that timber harvest increases total water yield (Fulton and West, 2002), there is less agreement on how timber harvest affects biogeochemical processes, nutrient export, and stream water chemistry. Previous studies have shown that biogeochemical trends observed after timber harvest are often confounded by specific watershed characteristics, such as watershed area, forest and vegetation types, soil types, slope, aspect, and light availability, to name a few (Lamontagne et al., 2000; Bernhardt et al., 2003). Determining the relationship between stand density reduction, streamflow, and fluxes of major cation, anions and nutrients across a range of harvest intensities will allow identifying thresholds at which reducing stand density may begin to affect biogeochemical processes to the extent that nutrient export and stream chemistry are significantly affected. The goal of the nutrient study is to quantify the effect of different levels of stand density reduction on the mass balance of major nutrients (carbon, nitrogen, and phosphorus) and base cations and anions in the South Fork Caspar Creek. Our main hypothesis is that stand density reduction will increase export of total $\mathrm{N}$, total $\mathrm{P}$, nitrate, and particulate and dissolved organic carbon from
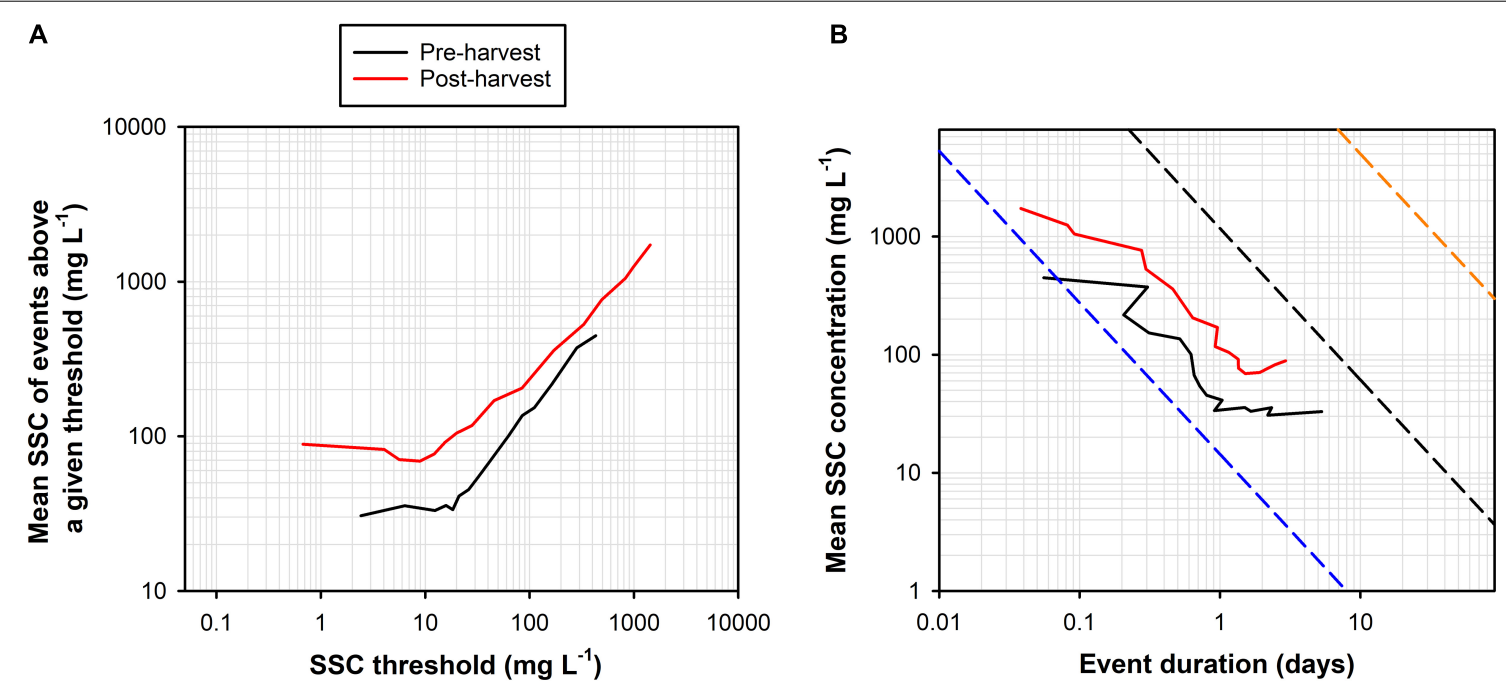

FIGURE 5 | Illustrative example of a magnitude-magnitude plot (A) and magnitude-duration plot (B) using pre- and post-harvest suspended sediment concentration (SSC) datasets from the Second Experiment in the North Fork. In (B) threshold levels from MODEL 3 included avoidance response (dotted blue line), moderated physiological stress (dotted black line), and reduced growth rate (dotted orange line). 
TABLE 4 | Area affected by ground-based or sky-line yarding methods, log-loading landings, and different classes of roads by sub-watershed in the South Fork of Caspar Creek.

\begin{tabular}{|c|c|c|c|c|c|c|c|c|c|}
\hline & \multirow[b]{2}{*}{ Area (ha) } & \multicolumn{2}{|c|}{ Yarding (ha) } & \multirow[b]{2}{*}{ New constr. } & \multicolumn{4}{|c|}{ Roads and landings (ha) } & \multirow[b]{2}{*}{ De-comm. } \\
\hline & & Ground-based & Sky-line cable & & Recon. & Perm. & County & Total & \\
\hline Ogilvie (OGl) & 19 & 5.9 & 7.2 & 0.31 & 0.16 & 0 & 0.16 & 0.63 & 0 \\
\hline Porter (POR) & 31 & 5 & 13.5 & 0.25 & 0.37 & 0 & 0.36 & 0.98 & 0 \\
\hline Richards (RIC) & 47 & 0 & 0 & 0 & 0 & 0 & 0.39 & 0.39 & 0 \\
\hline Sequoyah (SEQ) & 17 & 6 & 11.2 & 0.42 & 0.17 & 0 & 0 & 0.59 & 0 \\
\hline Treat (TRE) & 14 & 4.2 & 10.1 & 0.36 & 0.14 & 0 & 0.14 & 0.65 & 0 \\
\hline Uqlidisi (UQL) & 13 & 3.6 & 9.2 & 0.27 & 0.04 & 0 & 0.13 & 0.43 & 0.25 \\
\hline Williams (WIL) & 26 & 0 & 0 & 0 & 0 & 0 & 0.09 & 0.09 & 0.33 \\
\hline Yocom (YOC) $)^{a}$ & 28 & 0 & 0 & 0 & 0 & 0 & 0 & 0 & 0.28 \\
\hline Ziemer (ZIE) & 24 & 7.4 & 16.5 & 0.70 & 0.28 & 0 & 0.09 & 1.12 & 0.28 \\
\hline Matrix $^{\mathrm{b}}$ & 192 & 30.3 & 157.5 & 2.69 & 1.01 & 0.89 & 0.14 & 4.72 & 1.06 \\
\hline Quetelet (QUE) & 392 & 56.5 & 218 & 4.68 & 2.01 & 0.89 & 1.34 & 8.92 & 2.19 \\
\hline South Fork $(\mathrm{SFC})^{\mathrm{C}}$ & 417 & 62.6 & 229.3 & 4.99 & 2.16 & 1.13 & 1.51 & 9.79 & 2.19 \\
\hline
\end{tabular}

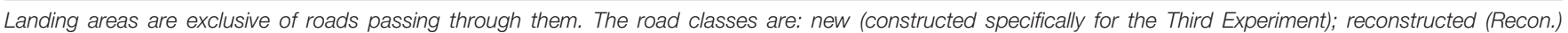

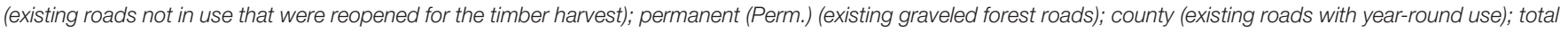

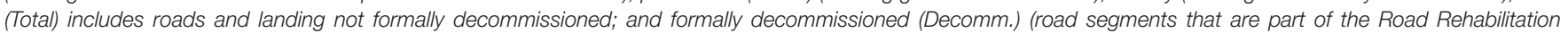

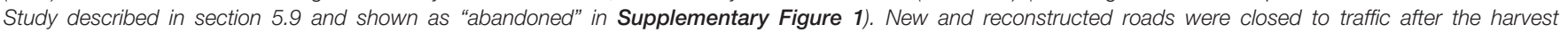
operations were completed.

${ }^{a}$ Excludes areas in ZIE. ${ }^{b}$ Matrix area within QUE not in gaged sub-watersheds. ${ }^{c}$ Includes small areas that drain directly to the weir pond in addition to OGI and QUE.

the treated watersheds immediately following the timber harvest, with greater effects observed with greater stand density reduction. The increased export of nutrients and base cations/anions is further hypothesized to be facilitated by rapid flow pathways and increased hydrologic connectivity associated with macropore flow and fast subsurface stormflow above the clay-rich, argillic soil horizon present in the watershed. This study is addressing the following specific research questions:

1) What are the annual, seasonal and event-based variations and patterns of nutrient and base cation/anion fluxes from coast redwood forests?

2) How do different stand density reductions change the patterns, concentrations and fluxes of nutrients and base cations and anions compared to pre-harvest conditions?

Between Fall 2016 and June 2020 over 1800 water samples were collected at the outlets of four sub-watersheds (TRE, WIL, UQL, and ZIE) and at the South Fork weir during storm events and during the summer baseflow period. Samples are being analyzed for electrical conductivity, $\mathrm{pH}$, and concentrations of total nitrogen, ammonium, nitrate, dissolved organic nitrogen, total phosphorus, phosphate, dissolved organic, and base cations and anions. Concentrations and loads will be compared in across the five sampling points and through time (pre- and post-harvest, water year, water year type, and season). Preliminary results show greatest nutrient flux events occurring during the onset of the winter/wet season and in early spring (McLaughlin et al., 2019), although laboratory work is ongoing.

\section{Interception and Throughfall Study}

Past research in the Caspar Creek watersheds and elsewhere have demonstrated that a significant proportion of rainfall can be intercepted by the forest canopy (Maidment, 1993). During the Second Experiment in the North Fork, canopy and basal interception measured $22 \%$ of rainfall, and it was hypothesized that reduction in interception from the clearcut harvest increased peak flows (Reid and Lewis, 2009). Canopy interception rates in the younger, uneven-aged managed coast redwood forest have not been investigated. A better understanding of the effects of current management and forest structure on interception will reduce the uncertainty in our ability to predict streamflow responses. This study addresses the following specific research objectives:

1) Determine the absolute and proportional amounts of precipitation intercepted by forest canopy and litter in the second and third-growth stands of the South Fork Caspar Creek.

2) Quantify the effects of the Third Experiment selective logging on forest canopy and litter layer interception rates in the South Fork of Caspar Creek.

3) Measure the changes in interception and net precipitation during the initial regrowth period.

4) Evaluate the role of interception on runoff after the Third Experimental harvest and compare it to the rates previously measured in the second-growth forest and following the Second Experiment in the North Fork of Caspar Creek (Reid and Lewis, 2009).

In 2006, we installed instruments in two opposing-aspect 1 ha plots to measure pre-harvest interception rates (Figure 3 ). Throughfall was collected in eight randomly located $1.5-\mathrm{m}^{2}$ platforms and routed through a tipping bucket mechanism connected to a continuously recording data logger. In addition, 20 non-recording ("roving") rain gages were randomly located 
and periodically re-positioned through the wet seasons. Throughfall was also measured underneath the litter and slash layer at 10 of the "roving" locations using ground-level containers packed with forest litter. At each site, gross precipitation was measured in a nearby canopy opening using a tipping bucket rain gauge paired with a platform collector and a non-recording rain gauge to match those used under the canopy. Measurements were made from November 2006 to August 2008. In 2019, instruments were reinstalled after the Third Experiment harvest and measurements will continue through 2021. A subset of throughfall and gross precipitation measurements will be made at 5-year post-harvest intervals to assess the effects of regrowth.

\section{Geomorphic Mapping}

During planning, preparation, and layout of the South Fork Caspar Timber Harvesting Plan (THP) (California Department of Forestry and Fire Protection (CAL FIRE), 2016) for the Third Experiment, the California Geological Survey (CGS) prepared an Engineering Geologic Report (California Geological Survey (CGS), 2016) following "Guidelines for Engineering Geologic Reports for Timber Harvesting” (California Geological Survey (CGS), 2013). Specific project tasks included review of pertinent geologic reports and maps relevant to the THP; geomorphic interpretation of $2004 \mathrm{LiDAR}$ data and stereoscopic aerial photographs; geomorphic field reconnaissance of the South Fork and adjacent area between November 2015 and August 2016; discussions with the Registered Professional Forester responsible for preparing the THP; analysis of geologic mitigations designed to minimize operational impacts on slope stability; and preparation of the report and accompanying geologic map. During our review, it was noted that landslide mapping efforts in the South Fork Caspar Creek had been conducted by numerous geologists and researchers, dating back to at least the mid1960s. The review showed that these mapping efforts were not always tied to one another and therefore presented a somewhat disordered assortment of landslide data in the South Fork Caspar Creek watershed. Additionally, preliminary field reconnaissance in November 2015 revealed the presence of landslides that were not identified on the maps reviewed by CGS.

As such, CGS conducted field-based geomorphic mapping of the South Fork Caspar Creek watershed between May and August 2016 in order to provide updated, georeferenced landslide information for use in the THP preparation and for further analysis of the Third Experiment. 2004 LiDAR data was used to generate hillshade imagery, topographic contours, and slope maps that were utilized during mapping. Additionally, multiple sets of historic aerial photographs were reviewed. The previously collected landslide data were reviewed and fieldchecked. New landslides were identified through a process of LiDAR interpretation and field-based confirmation, while field observations were recorded with a GPS.

The updated geologic mapping was then used in preparation of the South Fork Caspar THP. The primary objective of the assessment was to evaluate the potential impacts of the proposed timber harvesting operations on slope stability and resultant sediment delivery. Based on this assessment, mitigations were developed to reduce the potential for adverse geologic impacts associated with the proposed harvest and implemented during the timber harvest.

\section{Understory Evapotranspiration Study}

A century of paired-watershed studies have largely shown that forest harvesting can result in temporary increases in streamflow, while reforestation results in decreased streamflow (e.g., Hewlett and Hibbert, 1967 and Hibbert, 1967; Stednick, 1996). However, results can often seem to be conflicting, for example some harvests may temporarily decrease streamflow due to elevated water use by understory plants that have been had competition reduced (Johnson and Kovner, 1956; Greenwood et al., 1985). Surprisingly, few studies have attempted to quantify the amount of water used by understory vegetation following timber harvest or other types of disturbance. We hypothesize that increasing levels of stand density reduction will result in increased plant water use by both overstory and understory remaining vegetation due to decreased competition. The specific research goals of this study were to:

1) Quantify the evapotranspiration (ET) rate of common woody understory species native to coast redwood forests.

2) Compare the understory ET rates across a range of stand density reductions.

This study used a portable rapid ET chamber to directly measure understory plant water of evergreen huckleberry (Vaccinium ovatum Pursh), coast redwood, and tanoak in situ in the South Fork Caspar Creek (Hammerschmidt, 2020). Postharvest measurements were conducted in the TRE, UQL, WIL, and ZIE sub-watersheds in June and July 2019. Mean understory ET rate was highest in the highly harvested ZIE sub-watershed $(\bar{x}=4 \pm 2 \mathrm{~mm} / \mathrm{h})$ and lowest in the unharvested WIL subwatershed $(\bar{x}=1.6 \pm 0.92 \mathrm{~mm} / \mathrm{h}$ ) (Hammerschmidt, 2020). Multiple regression modeling suggested that the difference in ET rates across the treatments was caused by variations in soil water and light availability that resulted from the harvesting. This study was completed in 2020.

\section{Fog Dynamics Study}

The South Fork Caspar Creek watershed is located in the coastal California fog belt. Frequent summertime fog inundation is important for relieving plant water stress in the seasonally dry coast redwood forest (Means, 1927; Oberlander, 1956; Azevedo and Morgan, 1974; Dawson, 1998). Yet changes to a forest structure can change fog interception, thereby altering hydrologic dynamics of the ecosystem (Harr, 1982; Ingwersen, 1985; Dawson, 1998; Keppeler, 2007). Given the unique connection between seasonal fog and coast redwoods (e.g., Azevedo and Morgan, 1974; Fischer and Still, 2007; Fischer et al., 2016), this study addresses the following research questions:

1) How does canopy cover affect fog deposition in a coast redwood forest?

2) How does canopy cover affect soil moisture as influenced by fog water over the summer season?

3) How does canopy cover affect meteorological conditions during fog deposition? 
This study uses a sensor network to monitor canopy fog, wind speed and direction, ground wetness, and soil moisture in the shoulder and ridgetop positions of two sub-watersheds in the South Fork Caspar Creek. Sensors were installed in WIL (control) and ZIE (76\% basal area reduction) sub-watersheds in spring and early summer 2020 . The sites were monitored throughout the 2020 summer fog season to assess the meteorological drivers of fog in the South Fork and to determine the influences of forest density on fog water dynamics in this system. This study is anticipated to be completed in 2021.

\section{Vegetation Recovery Study}

Light is a fundamental driver of various ecosystem processes, from photosynthesis to evaporation to decomposition. Light plays a large role in recruitment of understory of coast redwood stands, with increased self-thinning of stump sprouts and decreased leaf-area-index (LAI) occurring in stands with poor light regimes (O'Hara and Berrill, 2010). Forest managers routinely alter the light environment in forests by removing trees via timber harvest, which promotes regeneration of some species (Oliver and Larson, 1990). Timber harvesting is a large pulse disturbance to an ecosystem, and results in different species and structure developing (i.e., secondary succession). The recovery of an ecosystem following such a disturbance will depend on myriad factors, including the severity of the disturbance, species composition prior to the disturbance, and regeneration strategies of the successional species. In the Caspar Creek Third Experiment, the hydrologic recovery following a range of harvest intensities is reliant on the vegetative recovery. Thus, monitoring the regeneration of the recovering forest is critical for understanding and informing many of the associated research objectives in the Third Experiment. Specifically, this study has the following research objectives:

1) Couple forest conditions (i.e., leaf-area-index) to ecohydrological processes across the range of stand density reduction in the sub-watersheds.

2) Assess the impact of the stand density reduction on long-term overstory and understory vegetation dynamics (structure, density, species, LAI, other metrics).

In summer 2020, 43 permanent vegetation plots were established across the South Fork Caspar Creek. These plots include understory monitoring that took place at 20 locations in summer 2019. Plots consist of three 0.05 ha $\left(500 \mathrm{~m}^{2}\right)$ circular plots at each site $\left(12.6 \mathrm{~m}\right.$ radius), with three square $1 \mathrm{~m}^{2}$ understory sampling sub-plots per overstory circular plot. In the larger overstory plots, percent canopy cover was estimated at four height classes $(0-0.62 \mathrm{~m},>0.62-1.83 \mathrm{~m},>1.83-4.88 \mathrm{~m}$, and $>4.88 \mathrm{~m}$ ). Percent ground cover was also estimated and categorized as lichen, litter/duff, mineral soil, moss, road/trail, rock, standing water/flooded, stream/lake, trash/junk/other, or wood. In the smaller understory plots, all vascular plants were identified, and their percent cover of the plot was estimated. Woody seedlings and sprouts and ferns were counted and the height of the tallest stem or frond of each species was measured. The diameter of saplings $(2.5-12.5 \mathrm{~cm},>1.37 \mathrm{~m}$ tall) was also measured. Leaf-area-index (LAI) was mapped at the subplot level using a LI-COR LAI-2200C plant canopy analyzer. Understory and overstory monitoring will continue annually through 2024, with periodic inventories likely to occur every 3-5 years until approximately canopy closure.

\section{HARVESTING IMPLEMENTATION AND RESULTS}

Three main considerations drove the design and implementation of the harvesting of the South Fork Caspar Creek for the Third Experiment. First, the experimental design prescribed a gradient of stand density reduction (i.e., intensity of harvest) across the treated sub-watersheds. Second, several of the subwatersheds had unique management constraints (see section "Selecting Control and Treatment Watersheds" and below). Lastly, pre-treatment stand conditions had to be considered in the overall management prescription. JDSF harvests are governed by both the CFPR and the JDSF Management Plan (FMP) (CAL FIRE, 2016). The latter includes measures to maintain visual standards on JDSF land bordering parks, county roads and private land when planning harvesting operations. Overlapping the FMP and CFPR requirements created a complex pattern of harvest limitations in the gaged sub-watersheds. To meet the Third Experiment's stand density reduction targets, subwatershed average harvesting intensities were determined by area-weighting the density reduction across the treated subwatersheds (Table 3 and Figure 3). For example, in ZIE, portions of the watershed were harvested above the target stand density reduction of $75 \%$, while other parts such as in the Watershed and Lake Protection Zone, were harvested below the target density reduction (Figures 3, 6).

The forest basal area was quantified by a series of pre-and post-harvest inventories. As is typical in the coast redwood region, measures of variability were high due to the propensity of coast redwood to grow in large clumps. Areas of high stand density reduction relied on variable retention methods and in some locations this compared to even-aged silviculture. In areas of high stand density reduction, retained trees were selected for potential wildlife habitat value, and thinning of small non-commercial (non-merchantable) trees was used to meet the density reduction goals. Planted redwood seedlings supplemented natural regeneration in Ogilvie and Ziemer. In areas with lower stand density reductions, single tree selection was used to enhance a multi-age structure. The matrix area was prescribed for uneven-aged management to reflect typical harvest prescriptions in the redwood region (Table 3 ). The north side of the matrix area had higher initial density and lower percent removed ( $\left.93 \mathrm{~m}^{2} / \mathrm{ha}, 38 \%\right)$ than the south $\left(76 \mathrm{~m}^{2} / \mathrm{ha}, 55 \%\right.$; Figure 3). The matrix area is included in both QUE and SFC inventories (Table 3).

Harvesting for the Third Experiment began in 2017 and ended in 2019 (Supplementary Figure 1). The harvest for the Third Experiment was also the third harvest in the South Fork, and it represents the historic progression of improved timber harvesting in the basin. The unregulated primary harvest of all 

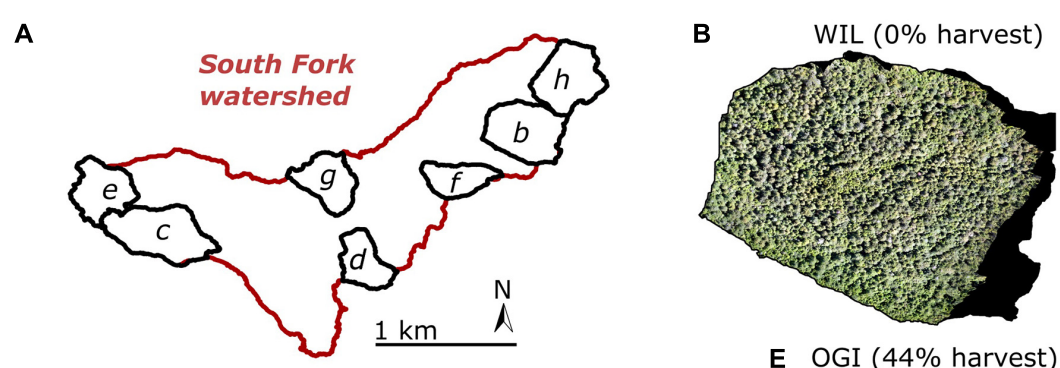

C $\operatorname{POR}(21 \%$ harvest)

D TRE (39\% harvest)
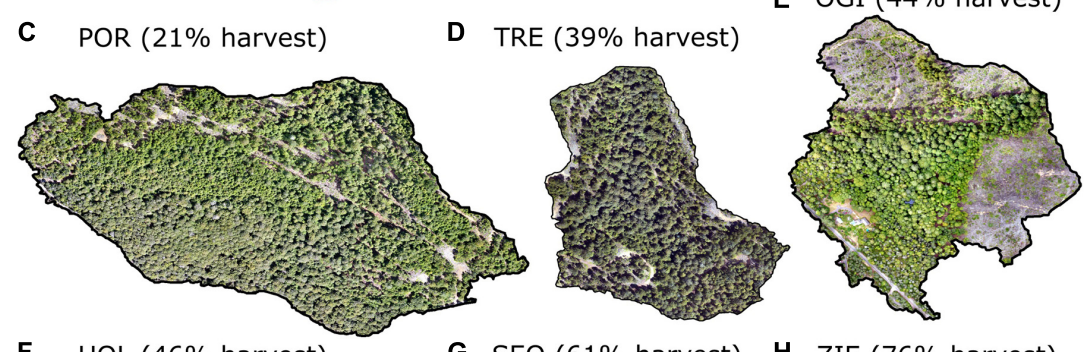

F UQL (46\% harvest)

G SEQ (61\% harvest)

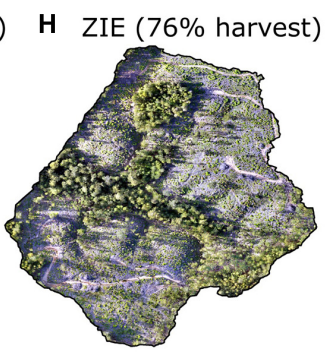

FIGURE 6 | Orthomosaics showing harvested sub-watersheds and a control sub-watershed (WIL). Panels (B-H) are marked on the map in panel (A). The images for the orthomosaics were collected with an unmanned aerial system (UAS) in spring 2020 after the Third Experiment harvesting was completed.

merchantable material, which was yarded using oxen, and splash dams or railroads was followed by a second partial harvest for the First Experiment with extensive downslope tractor yarding to riparian roads. Now the third harvest used a mix of methods to mitigate watershed impacts and achieve objectives. For the Third Experiment, sky-line cable systems were used to remove timber on steeper slopes. A tracked feller-buncher with rubbertired skidder was used on less steep ground. A processor was used for whole tree yarding at some cable landings. Transportation shifted from riparian roads in the First Experiment to ridgetop and upper slope roads in the Third Experiment (Supplementary Figure 1). In 1998, $4.2 \mathrm{~km}$ of main-haul riparian road had been formally decommissioned (Keppeler et al., 2007). With the 5 ha of new construction and reopening of 2.2 ha of previously closed roads, roaded area (including landigns) for the Third Experiment totaled $9.8 \mathrm{~km}$ (Table 4). These roads were closed to traffic after the harvest operations were completed.

\section{CONCLUDING REMARKS}

The paired watershed approach is a widely applied tool for experimentally determining the effects of land management on hydrologic processes. We designed the Third Experiment at the Caspar Creek Experimental Watersheds to test the effects of increasing levels of stand density reduction and associated forest access road management on net precipitation, soil moisture fluxes, groundwater recharge, evapotranspiration, streamflow, water exchange among hydrologic stores, erosion, turbidity, aquatic habitat and biota, understory and overstory regeneration, and nutrient and sediment dynamics (Figure 2). The large number of research studies related to this Third Experiment is a product of partnerships among university researchers, federal and state scientists and resource managers, local timber companies, and engaged community partners. It is truly an interdisciplinary effort to increase our knowledge of watershed processes and refine forest management practices that are guided by science.

\section{DATA AVAILABILITY STATEMENT}

The original contributions presented in the study are included in the article/ Supplementary Material, further inquiries can be directed to the corresponding author/s.

\section{AUTHOR CONTRIBUTIONS}

SD led writing of the manuscript and overall experimental design. PR made figures, assisted with writing, and performed the correlation analysis. LW analyzed the post-harvest data. All 
other authors contributed to writing the manuscript and various aspects of study and project design. All the authors contributed to the article and approved the submitted version.

\section{FUNDING}

The California Department of Forestry and Fire Protection and the USDA Forest Service provided funding for the experimental harvest and monitoring. Additional studies were supplemented with funding provided by NSF-EAR-1807165.

\section{ACKNOWLEDGMENTS}

The rich history of research and management at Caspar Creek is the result of the efforts of many scientists, resource managers, and

\section{REFERENCES}

Arismendi, I., Groom, J. D., Reiter, M., Johnson, S. L., Dent, L., Meleason, M., et al. (2017). Suspended sediment and turbidity after road construction/ improvement and forest harvest in streams of the Trask River Watershed Study, Oregon. Water Resour. Res. 53, 6763-6783. doi: 10.1002/2016WR020198

Arismendi, I., Johnson, S. L., and Dunham, J. B. (2015). Higher-order statistical moments and a procedure that detects potentially anomalous years as two alternative methods describing alterations in continuous environmental data. Hydrol. Earth Syst. Sci. 19, 1169-1180. doi: 10.5194/hess-19-1169-2015

Arismendi, I., Johnson, S. L., Dunham, J. B., and Haggerty, R. (2013). Descriptors of natural thermal regimes in streams and their responsiveness to change in the Pacific Northwest of North America. Freshw. Biol. 58, 880-894. doi: 10.1111/ fwb. 12094

Azevedo, J., and Morgan, D. L. (1974). Fog precipitation in Coastal California forests. Ecology 55, 1135-1141. doi: 10.2307/1940364

Bates, C. G. (1921). First results in the streamflow experiment, Wagon Wheel Gap, Colorado. J. For. 19, 402-408.

Bernhardt, E. S., Likens, G. E., Buso, D. C., and Driscoll, C. T. (2003). In-stream uptake dampens effects of major forest disturbance on watershed nitrogen export. Proc. Natl. Acad. Sci. U. S. A. 100, 10304-10308. doi: 10.1073/pnas. 1233676100

Beschta, R., Bilby, R., Brown, G., Holtby, L. B., and Hostra, T. D. (1987). "Stream temperature and aquatic habitat: fisheries and forestry interactions," in Streamside Management: Forestry and Fishery Interactions eds E. Salo and T. W. Cundy. (Seattle, WA: University of Washington), 191-232.

Beschta, R. L. (1978). Long-term patterns of sediment production following road construction and logging in the Oregon Coast Range. Water Resour. Res. 14, 1011-1016. doi: 10.1029/wr014i006p01011

Biederman, J. A., Somor, A. J., Harpold, A. A., Gutmann, E. D., Breshears, D. D., Troch, P. A., et al. (2015). Recent tree die-off has little effect on streamflow in contrast to expected increases from historical studies. Water Resour. Res. 51, 9775-9789. doi: 10.1002/2015WR017401

Bilby, R. E., Sullivan, K., and Duncan, S. H. (1989). The generation and fate of roadsurface sediment in forested watersheds in Southwestern Washington. For. Sci. 35, 453-468.

Bladon, K. D., Bywater-Reyes, S., LeBoldus, J. M., Keriö, S., Segura, C., Ritóková, G., et al. (2019). Increased streamflow in catchments affected by a forest disease epidemic. Sci. Total Environ. 691, 112-123. doi: 10.1016/j.scitotenv.2019.07.127

Brooks, J. R., Barnard, H. R., Coulombe, R., and McDonnell, J. J. (2010). Ecohydrological separation of water between streams and trees in a Mediterranean climate. Nat. Geosci. 3, 100-104. doi: 10.1038/NGEO722

Brown, A. E., Zhang, L., McMahon, T. A., Western, A. W., and Vertessy, R. A. (2005). A review of paired catchment studies for determining changes in water yield resulting from alterations in vegetation. J. Hydrol. 310, 28-61. doi: 10. 1016/j.jhydrol.2004.12.010 students over the past six decades. We are grateful for the efforts of Dr. Bob Ziemer, Dr. Tom Lisle, Dr. Matt Busse, Rand Eads, and Jack Lewis to establish the Third Experiment. Thank you to Dr. Leslie Reid for her contributions to experimental design and context analysis. Special thanks to the USFS PSW Caspar and CAL FIRE field crews and to Kirk O'Dwyer for developing the Timber Harvest Plan. Thanks to Dr. Jeff Hatten, Oregon State University, for leading the sediment fingerprinting study. Finally, thank you to CAL FIRE and the USDA Forest Service for continued funding of this long-term research study.

\section{SUPPLEMENTARY MATERIAL}

The Supplementary Material for this article can be found online at: https://www.frontiersin.org/articles/10.3389/ffgc.2021. 691732/full\#supplementary-material

Brown, G. W., and Krygier, J. T. (1970). Effects of clear cutting on stream temperature. Water Resour. Res. 6, 1133-1139. doi: 10.1029/wr006i004p 01133

Cafferata, P. H., and Reid, L. M. (2013). Applications of Long-Term Watershed Research to Forest Management in California: 50 Years of Learning from the Caspar Creek Experimental Watersheds. California Forestry Report No. 5. Sacramento, CA: State of California Department of Forestry and Fire Protection, 110 .

California Department of Forestry and Fire Protection (CAL FIRE) (2016). Jackson Demonstration State Forest Management Plan, 2016 Update. Sacramento, CA: State of California Natural Resources Agency.

California Geological Survey (CGS) (2013). Note 45, Guidelines For Engineering Geologic Reports For Timber Harvesting Plans. Reston, VA: California Geological Survey. dated January.

California Geological Survey (CGS) (2016). Engineering Geologic Report, South Fork Caspar Timber Harvesting Plan (THP 1-16-124 MEN), Jackson Demonstration State Forest (JDSF); Prepared by Patrick Brand; dated November 16; Also Includes Report Addendum Dated January 24, 2017.

Carr, A. E., Loague, K., and VanderKwaak, J. E. (2013). Hydrologic-response simulations for the North Fork of caspar creek: second-growth, clear-cut, newgrowth, and CWE scenarios. Hydrol. Process. 28, 1476-1494. doi: 10.1002/hyp. 9697

Carroll, G. D., Schoenholtz, S. H., Young, B. W., and Dibble, E. D. (2004). Effectiveness of forestry streamside management zones in the sand-clay hills of Mississippi: early indications. Water Air Soil Pollut. Focus 4, 275-296. doi: 10.1023/b:wafo.0000012813.94538.c8

Clausen, J. C., and Spooner, J. (1993). Paired Watershed Study Design. USEPA Natl. Lib. Netwk. Publ. 841-F-93-009. Washington, DC: USEPA.

Coble, A. A., Barnard, H., Du, E., Johnson, S., Jones, J., Keppeler, E., et al. (2020). Long-term hydrological response to forest harvest during seasonal low flow: potential implications for current forest practices. Sci. Total Environ. 730:138926. doi: 10.1016/j.scitotenv.2020.138926

Collins, A. L., and Walling, D. E. (2002). Selecting fingerprint properties for discriminating potential suspended sediment sources in river basins. J. Hydrol. 261, 218-244. doi: 10.1016/s0022-1694(02)00011-2

Collins, A. L., and Walling, D. E. (2004). Documenting catchment suspended sediment sources: problems, approaches and prospects. Prog. Phys. Geogr. 28, 159-196. doi: 10.1191/0309133304pp409ra

Collins, A. L., Walling, D. E., Webb, L., and King, P. (2010). Apportioning catchment scale sediment sources using a modified composite fingerprinting technique incorporating property weightings and prior information. Geoderma 155, 249-261. doi: 10.1016/j.geoderma.2009.12.008

Cristan, R., Aust, W. M., Bolding, M. C., Barrett, S. M., Munsell, J. F., and Schilling, E. (2016). Effectiveness of forestry best management practices in the United States: literature review. For. Ecol. Manag. 360, 133-151. doi: 10.1016/j. foreco.2015.10.025 
Croke, J. C., and Hairsine, P. B. (2006). Sediment delivery in managed forests: a review. Environ. Rev. 14, 59-87. doi: 10.1139/a05-016

Dawson, T. E. (1998). Fog in the California redwood forest: ecosystem inputs and use by plants. Oecologia 117, 476-485. doi: 10.1007/s004420050 683

Diehl, T. H., and Wolfe, W. J. (2010). Suspended-sediment concentration regimes for two biological reference streams in middle Tennessee. J. Am. Water Resour. Assoc. 46, 824-837. doi: 10.1111/j.1752-1688.2010.00460.x

Dugdale, S. J., Hannah, D. M., and Malcolm, I. A. (2017). River temperature modelling: a review of process-based approaches and future directions. Earth Sci. Rev. 175, 97-113. doi: 10.1016/j.earscirev.2017.10.009

Ebel, B. A., and Mirus, B. B. (2014). Disturbance hydrology: challenges and opportunities. Hydrol. Process. 28, 5140-5148. doi: 10.1002/hyp.10256

Fischer, D. T., and Still, C. J. (2007). Evaluating patterns of fog water deposition and isotopic composition on the California Channel Islands. Water Resour. Res. $43,1-13$.

Fischer, D. T., Still, C. J., Ebert, C. M., Baguskas, S. A., and Park Williams, A. (2016). Fog drip maintains dry season ecological function in a California coastal pine forest. Ecosphere 7:e01364. doi: 10.1002/ecs2.1364

Fulton, S., and West, B. (2002). Forestry impacts on water quality. South. For. Resour. Assessment 21:635.

Grant, G., Hayes, S., and Lewis, S. (2003). "Effect of peak flow increases on sediment transport regimes following timber harvest, western Cascades, Oregon. Abstract," in First Interagency Conference on Research in the Watersheds, October 27-30, 2003, eds K. G. Renard, S. A. McElroy, W. J. Gburek, H. E. Canfield, and R. L. Scott (Washington, DC: U.S. Department of Agriculture).

Grayson, R. B., Haydon, S. R., Jayasuriya, M. D. A., and Finlayson, B. L. (1993) Water-quality in mountain ash forests - separating the impacts of roads from those of logging operations. J. Hydrol. 150, 459-480. doi: 10.1016/00221694(93)90121-o

Greenwood, E. A. N., Klein, L., Beresford, J. D., Watson, G. D., and Wright, K. D. (1985). Evaporation from the understory in the Jarrah Forest, Southwestern Australia. J. Hydrol. 80, 337-349. doi: 10.1016/0022-1694(85)90126-x

Hammerschmidt, S. R. (2020). Understory Transpiration Rates Following Stand Density Reduction in a Coast Redwood Forest. Ph.D. thesis. St. Paul, MN: The University of Minnesota Twin Cities.

Harr, D. R. (1982). Fog drip in the bull run municipal watershed, Oregon. Water Resour. Bull. 18, 785-789. doi: 10.1111/j.1752-1688.1982.tb00073.x

Hatten, J. A., Segura, C., Bladon, K. D., Hale, V. C., Ice, G. G., and Stednick, J. D. (2018). Effects of contemporary forest harvesting on suspended sediment in the Oregon Coast Range: alsea watershed study revisited. For. Ecol. Manag. 408, 238-248. doi: 10.1016/j.foreco.2017.10.049

Henry, N. (1998). "Overview of the caspar creek watershed study," in Proceedings of the Conference on Coastal Watersheds: The Caspar Creek Story. Gen. Tech. Rep. PSW GTR-168, ed. R. R. Ziemer (Albany, CA: U.S. Department of Agriculture), 149.

Hewlett, J. D., and Hibbert, A. R. (1967). "Factors affecting the response of small watersheds to precipitation in humid areas," in Forest Hydrology, eds. W. E. Sopper, and H. W. Lull, (New York: Pergamon Press), 275-90.

Hibbert, A. R. (1967). "Forest treatment effects on water yield," in Proceedings of the International Symposium on Forest Hydrology, Pennsylvania, September 1965, eds W. E. Sopper and H. W. Lull (Permagon: Oxford).

Ingwersen, J. B. (1985). Fog drip, water yield, and timber harvesting in the Bull Run Municipal Watershed, Oregon. Water Resour. Bull. 21, 469-473. doi: 10.1111/j.1752-1688.1985.tb00158.x

Johnson, E. A., and Kovner, J. L. (1956). Effect on streamflow of cutting a forest understory. For. Sci. 2, 83-91.

Johnson, S. L., and Jones, J. A. (2000). Stream temperature responses to forest harvest and debris flows in western Cascades, Oregon. Can. J. Fish. Aquat. Sci. 57, 30-39. doi: 10.1139/f00-109

Karwan, D. L., Gravelle, J. A., and Hubbart, J. A. (2007). Effects of timber harvest on suspended sediment loads in Mica Creek, Idaho. For. Sci. 53, 181-188.

Kastridis, A. (2020). Impacts of forests on hydrological processes. Forests 11:1201. doi: $10.3390 /$ f11111201

Keppeler, E. (2007). "Effects of timber harvest on fog drip and streamflow, Caspar Creek Experimental Watersheds, Mendocino County, California. (2007)," in Proceedings of the Redwood Region Forest Science Symposium: What Does the Future Hold? Gen. Tech. Rep. PSW-GTR-194, eds R. B. Standiford, G. A. Giusti,
Y. Valachovic, W. J. Zielinski, and M. J. Furniss (Albany, CA: U.S. Department of Agriculture), 85-94.

Keppeler, E. T., Cafferata, P. H., and Baxter, W. T. (2007). State Forest Road 600: A Riparian Road Decommissioning Case Study in Jackson Demonstration State Forest. California Forestry Note No. 120. Sacramento, CA: California Department of Forestry and Fire Protection, 23.

Keppeler, E. T., and Lewis, J. (2007). “Understanding the hydrologic consequences of timber harvest and roading: four decades of streamflow and sediment results from the Caspar Creek Experimental Watersheds," in Advancing the Fundamental Sciences: Proceedings of the Forest Service National Earth Sciences Conference, San Diego, CA, 18-22 October 2004. Gen. Tech. Rep. PNW-GTR689, eds M. Furniss, C. Clifton, and K. Ronnenberg (Portland, OR: U.S. Forest Service), 577.

Keppeler, E., Reid, L., and Lisle, T. (2009). "Long-term patterns of hydrologic response after logging in a coastal redwood forest," in Planning for an Uncertain Future-Monitoring, Integration, and Adaptation. Proceedings of the Third Interagency Conference on Research in the Watersheds: U.S. Geological Survey Scientific Investigations Report 2009-5049, eds R. M. T. Webb, and D. J. Semmens, 265-272.

Keppeler, E. T., and Ziemer, R. R. (1990). Logging effects on streamflow - water yield and summer low flows at Caspar Creek in northwestern California. Water Resour. Res. 26, 1669-1679. doi: 10.1029/wr026i007p01669

Kinoshita, A. M., and Hogue, T. S. (2015). Increased dry season water yield in burned watersheds in Southern California. Environ. Res. Lett. 10:9. doi: 10.1088/ 1748-9326/10/1/014003

Lamontagne, S., Carignan, R., D’Arcy, P., Prairie, Y. T., and Paré, D. (2000). Element export in runoff from eastern Canadian Boreal Shield drainage basins following forest harvesting and wildfires. Can. J. Fish. Aquat. Sci. 57, 118-128. doi: $10.1139 /$ f00- 108

Langenheim, V. E., Jachens, R. C., Wentworth, C. M., and McLaughlin, R. J. (2013). Previously unrecognized regional structure of the Coastal Belt of the Franciscan Complex, Northern California, revealed by magnetic data. Geosphere 9, 15141529. doi: $10.1130 /$ ges00942.1

Lewis, J., and Eads, R. (2009). Implementation Guide for Turbidity Threshold Sampling: Principles, Procedures, and Analysis. Gen. Tech. Rep. PSW-GTR-212. Albany, CA: U.S. Department of Agriculture, 87.

Lewis, J., Mori, S. R., Keppeler, E. T., and Ziemer, R. R. (2001). "Impacts of logging on storm peak flows, flow volumes and suspended sediment loads in Caspar Creek, California," in Land Use and Watersheds: Human Influence on Hydrology and Geomorphology in Urban and Forest Areas. Water Science and Application, Vol. 2, eds M. S. Wigmosta and S. J. Burges (Washington, D.C: American Geophysical Union), 85-125. doi: 10.1029/ws002p0085

Lisle, T. E. (1989). Sediment transport and resulting deposition in spawning gravels, north coastal California. Water Resour. Res. 25, 1303-1319. doi: 10. 1029/wr025i006p01303

Loehle, C., Wigley, T. B., Lucier, A., Schilling, E., Danehy, R., and Ice, G. (2014). Towards improved water quality in forestry: opportunities and challenges in a changing regulatory environment. J. For. 112, 41-47. doi: 10.5849/jof.12-111

Lugo, A. D., Swanson, F. J., González, O. R., Adams, M. B., Palik, B., Thill, R. E., et al. (2006). Long-term research at the USDA Forest Service's experimental forests and ranges. BioScience 56, 39-48.

Maidment, D. R. (ed.) (1993). Handbook of Hydrology. New York, NY: McGrawHill, Inc.

McDonnell, J. J., Evaristo, J., Bladon, K., Buttle, J., Creed, I., Dymond, S. F., et al. (2018). Water sustainability and watershed storage. Nat. Sustain. 1, 378-379.

McLaughlin, S. G., Dahlke, H. E., and Dahlgren, R. A. (2019). Impacts of Timber Harvest Treatments on Stream Biogeochemistry in a Northern California Redwood Stream. American Geophysical Union, Fall Meeting 2019, abstract \#H43G-2073. Available online at: https://ui.adsabs.harvard.edu/abs/ 2019AGUFM.H43G2073M/abstract

Means, T. H. (1927). Fog precipitated by trees. Science 66, 402-403. doi: 10.1126/ science.66.1713.402

Motha, J. A., Wallbrink, P. J., Hairsine, P. B., and Grayson, R. B. (2003). Determining the sources of suspended sediment in a forested catchment in southeastern Australia. Water Resour. Res. 39:1056.

Neary, D. G. (2016). Long-term forest paired catchment studies: what do they tell us that landscape-level monitoring does not? Forests 7:164. doi: 10.3390/f7080164 
Niemeyer, R. J., Bladon, K. D., and Woodsmith, R. D. (2020). Long-term hydrologic recovery after wildfire and post-fire forest management in the interior Pacific Northwest. Hydrol. Process. 34, 1182-1197. doi: 10.1002/hyp.13665

Oberlander, G. T. (1956). Summer fog precipitation on the San Francisco Peninsula. Ecology 37, 851-852. doi: 10.2307/1933081

Ode, P. R., Fetscher, A. E., and Busse, L. B. (2016a). Standard Operating Procedures for the Collection of Field Data for Bioassessments of California Wadeable Streams: Benthic Macroinvertebrates, Algae, and Physical Habitat. California State Water Resources Control Board Surface Water Ambient Monitoring Program (SWAMP) Bioassessment SOP 004.

Ode, P. R., Kincaid, T. M., Fleming, T., and Rehn, A. C. (2011). Ecological Condition Assessments of California's Perennial Wadeable Streams: Highlights from the Surface Water Ambient Monitoring Program's Perennial Streams Assessment (PSA) (2000-2007). A collaboration between the State Water Resources Control Board's Non-Point Source Pollution Control Program (NPS Program), Surface Water Ambient Monitoring Program (SWAMP), California Department of Fish and Game Aquatic Bioassessment Laboratory, and the U.S. Environmental Protection Agency. 89. Available online at: https://www.waterboards.ca.gov/ water_issues/programs/swamp/docs/reports/psa_smmry_rpt.pdf

Ode, P. R., Rehn, A. C., Mazor, R. D., Schiff, K. C., Stein, E. D., May, J. T., et al. (2016b). Evaluating the adequacy of a reference-site pool for ecological assessments in environmentally complex regions. Freshw. Sci. 35, 237-248. doi: $10.1086 / 684003$

O’Hara, K. L., and Berrill, J.-P. (2010). Dynamics of coast redwood sprout clump development in variable light environments. J. For. Res. 15, 131-139. doi: 10.1007/s10310-009-0166-0

Oliver, C. D., and Larson, B. C. (1990). Forest Stand Dynamics. New York, NY: McGraw-Hill, Inc., 544.

Pearce, A. J., Steward, M. K., and Sklash, M. G. (1986). Storm runoff generation in humid headwater catchments: 1 . Where does the water come from? Water Resour. Res. 22, 1263-1272. doi: 10.1029/wr022i008p01263

Perry, T. D., and Jones, J. A. (2017). Summer streamflow deficits from regenerating Douglas-fir forest in the Pacific Northwest, USA. Ecohydrology 10:13. doi: 10. 1002/eco.1790

Phillips, J. M., Russell, M. A., and Walling, D. E. (2000). Time-integrated sampling of fluvial suspended sediment: a simple methodology for small catchments. Hydrol. Process. 14, 2589-2602. doi: 10.1002/1099-1085(20001015)14: $14<2589::$ aid-hyp94>3.0.co;2-d

Reid, L. M. (2012). "Comparing hydrologic responses to tractor-yarded selection and cable-yarded clearcut logging in a coast redwood forest," in Proceedings of Coast Redwood Forests in a Changing California: A Symposium for Scientists and Managers. Gen. Tech. Rep. PSW-GTR-238. R. B. Standiford, T. J. Weller, D. D. Piirto, and J. D. Stuart (Albany, CA: U.S. Department of Agriculture), 151-161.

Reid, L. M., and Dunne, T. (1984). Sediment production from forest road surfaces. Water Resour. Res. 20, 1753-1761. doi: 10.1029/wr020i011p01753

Reid, L. M., and Lewis, J. (2009). Rates, timing, and mechanisms of rainfall interception loss in a coastal redwood forest. J. Hydrol. 375, 459-470. doi: 10.1016/j.jhydrol.2009.06.048

Rice, R. M., Tilley, F. B., and Datzman, P. A. (1979). A Watershed's Response to Logging and Roads: South Fork of Caspar Creek, California, 1967-1976. Research Paper PSW-146. Berkeley, CA: USDA Forest Service, 12.

Richardson, K. N. D., Hatten, J. A., and Wheatcroft, R. A. (2018). 1500 years of lake sedimentation due to fire, earthquakes, floods and land clearance in the Oregon Coast Range: geomorphic sensitivity to floods during timber harvest period. Earth Surf. Process. Landforms 43, 1496-1517. doi: 10.1002/esp.4335

Ridgeway, J. (2019). An Analysis of Changes in Stream Temperature Due to Forest Harvest Practices Using DHSVM-RBM. M.S. thesis. California Polytechnic State University, San Luis Obispo, CA.

Ridgeway, J. B., and Surfleet, C. G. (2021). Effects of streamside buffers on stream temperatures associated with forest management and harvesting using DHSVM-RBM; South Fork Caspar Creek, California. Front. For. Glob. Change 63. doi: $10.3389 /$ ffgc. 2021.611380
Rittiman, C. A., and Thorson, T. (2006). Soil Survey of Mendocino County, California, Western Part. Washington, DC: U.S. Department of Agriculture, 456.

Searcy, J. K., and Hardison, C. H. (1960). Double-Mass Curves. Manual of Hydrology: Part 1. General Surface-Water Techniques. Geological Survey WaterSupply Paper 1541-B. Washington, DC: U. S. Department of the Interior.

Sedell, J., Sharpe, M., Dravnieks Apple, D., Copenhagen, M., and Furniss, M. (2000). Water and the Forest Service. Policy Analysis FS-660. Washington, DC: USDA Forest Service, 40.

Segura, C., Bladon, K. D., Hatten, J. A., Jones, J. A., Hale, V. C., and Ice, G. G. (2020). Long term effects of forest harvesting on summer low flow deficits in the Coast Range of Oregon. J. Hydrol. 585:124749. doi: 10.1016/j.jhydrol.2020. 124749

Sosa-Pérez, G., and MacDonald, L. (2016). Reductions in road sediment production and road stream conductivity from two decommissioning treatments. For. Ecol. Manag. 398, 116-129. doi: 10.1016/j.foreco.2017.04.031

Stednick, J. D. (1996). Monitoring the effects of timber harvest on annual water yield. J. Hydrol. 176, 79-95. doi: 10.1016/0022-1694(95)02780-7

Surfleet, C. (2020). Evaluation of Forest Road Scenarios Using Field Measurements and DHSVM Modelling of the South Fork of Caspar Creek. Final Report prepared for the California Department of Forestry and Fire Protection; Contract No. 8CA03637. San Luis Obispo, CA: Cal Poly State University, 71.

Tague, C. L., Moritz, M., and Hanan, E. (2019). The changing water cycle: the ecohydrologic impacts of forest density reduction in Mediterranean (seasonally dry) regions. WIREs Water 6:e1350. doi: 10.1002/wat2.1350

US EPA (2017). National Rivers and Streams Assessment 2018/19: Field Operations Manual - Wadeable. EPA-841-B-17-003a. Washington, DC: U.S. Environmental Protection Agency.

Walling, D. E. (2005). Tracing suspended sediment sources in catchments and river systems. Sci. Total Environ. 344, 159-184. doi: 10.1016/j.scitotenv.2005.02.011

Wemple, B., Jones, J., and Grant, G. (1996). Channel network extension by logging roads in two basins, western Cascades, Oregon. Water Resour. Bull. 32, 1195-1207. doi: 10.1111/j.1752-1688.1996.tb03490.x

Wigmosta, M. S., Vail, L., and Lettenmaier, D. P. (1994). A distributed hydrology model for complex terrain. Water Resour. Res. 30, 1665-1679. doi: 10.1029/ 94wr00436

Woodard, M. E., Slusark, J., and Ode, P. R. (2012). Standard Operating Procedures for Laboratory Processing and Identification of Benthic Macroinvertebrates in California. California State Water Resources Control Board Surface Water Ambient Monitoring Program (SWAMP) Bioassessment SOP 003. Available online at: http://citeseerx.ist.psu.edu/viewdoc/download?doi=10.1.1.370.4948\& rep=rep1\&type $=$ pdf

Wright, K. A., Sendek, K. H., Rice, R. M., and Thomas, R. B. (1990). Logging effects on streamflow: storm runoff at Caspar Creek in northwestern California. Water Resour. Res. 26, 1657-1677. doi: 10.1029/wr026i007p01657

Zemke, J. J. (2016). Runoff and soil erosion assessment on forest roads using a small scale rainfall simulator. J. Hydrol. 3:25. doi: 10.3390/hydrology3030025

Ziemer, R. R. (1998). Proceedings of the Conference on Coastal Watersheds: the Caspar Creek Story. Gen. Tech. Rep. PSW-GTR-168. Albany, CA: USDA Forest Service, 149.

Conflict of Interest: The authors declare that the research was conducted in the absence of any commercial or financial relationships that could be construed as a potential conflict of interest.

Copyright (c) 2021 Dymond, Richardson, Webb, Keppeler, Arismendi, Bladon, Cafferata, Dahlke, Longstreth, Brand, Ode, Surfleet and Wagenbrenner. This is an open-access article distributed under the terms of the Creative Commons Attribution License (CC BY). The use, distribution or reproduction in other forums is permitted, provided the original author(s) and the copyright owner(s) are credited and that the original publication in this journal is cited, in accordance with accepted academic practice. No use, distribution or reproduction is permitted which does not comply with these terms. 